\title{
Ethane, ethyne and carbon monoxide concentrations in the upper troposphere and lower stratosphere from ACE and GEOS-Chem: a comparison study
}

\author{
G. González Abad ${ }^{1}$, N. D. C. Allen ${ }^{1}$, P. F. Bernath ${ }^{1}$, C. D. Boone ${ }^{2}$, S. D. McLeod ${ }^{2}$, G. L. Manney ${ }^{3,4}$, G. C. Toon ${ }^{3}$,

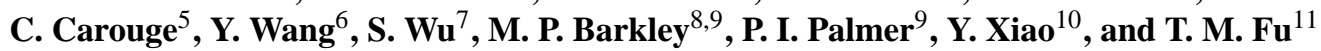 \\ ${ }^{1}$ Department of Chemistry, University of York, York, UK \\ ${ }^{2}$ Department of Chemistry, University of Waterloo, Waterloo, Ontario, Canada \\ ${ }^{3}$ NASA Jet Propulsion Laboratory, California Institute of Technology, Pasadena, California, USA \\ ${ }^{4}$ Department of Physics, New Mexico Institute of Mining and Technology, Socorro, New Mexico, USA \\ ${ }^{5}$ Department of Earth and Planetary Sciences and Division of Engineering and Applied Sciences, Harvard University, \\ Cambridge, Massachusetts, USA \\ ${ }^{6}$ Department of Environmental Science and Engineering, Tsinghua University, Beijing, China \\ ${ }^{7}$ Department of Geological and Mining Engineering and Sciences \& Department of Civil and Environmental Engineering, \\ Michigan Technological University, Houghton MI, USA \\ ${ }^{8}$ EOS Group, College of Science and Engineering, University of Leicester, UK \\ ${ }^{9}$ School of GeoSciences, University of Edinburgh, UK \\ ${ }^{10}$ Atmospheric and Environmental Research, Inc., Lexington, MA, USA \\ ${ }^{11}$ Department of Atmospheric and Oceanic Science, School of Physics, Peking University, China
}

Received: 26 November 2010 - Published in Atmos. Chem. Phys. Discuss.: 28 April 2011

Revised: 19 August 2011 - Accepted: 15 September 2011 - Published: 27 September 2011

\begin{abstract}
Near global upper tropospheric concentrations of carbon monoxide $(\mathrm{CO})$, ethane $\left(\mathrm{C}_{2} \mathrm{H}_{6}\right)$ and ethyne $\left(\mathrm{C}_{2} \mathrm{H}_{2}\right)$ from ACE (Atmospheric Chemistry Experiment) Fourier transform spectrometer on board the Canadian satellite SCISAT- 1 are presented and compared with the output from the Chemical Transport Model (CTM) GEOS-Chem. The retrievals of ethane and ethyne from ACE have been improved for this paper by using new sets of microwindows compared with those for previous versions of ACE data. With the improved ethyne retrieval we have been able to produce a near global upper tropospheric distribution of $\mathrm{C}_{2} \mathrm{H}_{2}$ from space. Carbon monoxide, ethane and ethyne concentrations retrieved using ACE spectra show the expected seasonality linked to variations in the anthropogenic emissions and destruction rates as well as seasonal biomass burning activity. The GEOS-Chem model was run using the dicarbonyl chemistry suite, an extended chemical mechanism in which ethyne is treated explicitly. Seasonal cycles observed from satellite data are well reproduced by the model output, however the
\end{abstract}

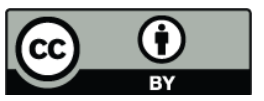

Correspondence to: G. González Abad (gga500@york.ac.uk) simulated CO concentrations are found to be systematically biased low over the Northern Hemisphere. An average negative global mean bias of $12 \%$ and $7 \%$ of the model relative to the satellite observations has been found for $\mathrm{CO}$ and $\mathrm{C}_{2} \mathrm{H}_{6}$ respectively and a positive global mean bias of $1 \%$ has been found for $\mathrm{C}_{2} \mathrm{H}_{2}$. ACE data are compared for validation purposes with MkIV spectrometer data and Global Tropospheric Experiment (GTE) TRACE-A campaign data showing good agreement with all of them.

\section{Introduction}

The Volatile Organic Compounds (VOCs) ethane $\left(\mathrm{C}_{2} \mathrm{H}_{6}\right)$ and ethyne $\left(\mathrm{C}_{2} \mathrm{H}_{2}\right)$ are two of the most important tropospheric organic trace gases. Ethane is the second most abundant hydrocarbon in the atmosphere and has a lifetime of approximately two months (Rudolph, 1995) whereas ethyne has a shorter lifetime estimated to be between two and four weeks (Logan et al., 1981). The main sink for non methane hydrocarbons (NMHC) in the free troposphere are reactions with hydroxyl radical $(\mathrm{OH})$. Ethane has a significant impact on

Published by Copernicus Publications on behalf of the European Geosciences Union. 
air quality as it is a strong source of PAN (peroxyacetyl nitrate), a reservoir for nitrogen dioxide. PAN has a major effect on tropospheric ozone, which is a strong greenhouse gas and also a toxic air pollutant (Rudolph, 1995). The main sources of ethane include biomass burning emissions, natural gas loss and biofuel consumption (Rudolph, 1995; Xiao et al., 2008). Ethyne's main sources include natural gas, biofuel combustion products and biomass burning emissions (Gupta et al., 1998; Logan et al., 1981; Rudolph, 1995; Xiao et al., 2007; Zhao et al., 2002). Ethyne may act as a precursor of Secondary Organic Aerosols (SOA) through the formation of glyoxal, a by-product from of its oxidation by $\mathrm{OH}$ (Volkamer et al., 2009).

Carbon monoxide (CO) is a key gas tracer in the troposphere. Sources in the troposphere include oxidation of methane and other hydrocarbons, biomass burning and anthropogenic emissions. Reaction with the hydroxyl radical is the main sink of CO. Carbon monoxide's lifetime in the troposphere is about two months. Its reaction with $\mathrm{OH}$ has an impact on the tropospheric chemistry of ozone and other important greenhouse gases such as methane (Logan et al., 1981; Turquety et al., 2008).

All together these species are three of the most important NMVOCs (Non Methane Volatile Organic Compounds) in the free troposphere. They play a key role in ozone chemistry through their reactions with $\mathrm{OH}$, and therefore are important for air quality and human health.

Notholt et al. (1997); Rinsland et al. (2002) and Zhao et al. (2002) have all retrieved $\mathrm{CO}, \mathrm{C}_{2} \mathrm{H}_{6}$ and $\mathrm{C}_{2} \mathrm{H}_{2}$ using ground based FTIRs (Fourier Transform Infrared Spectrometers) from solar and lunar measurements. Carbon monoxide concentrations from space have been obtained by many different instruments such as SCIAMACHY, MOPITT, and TES (Buchwitz et al., 2006; Deeter et al., 2003; Luo et al., 2007) that have a nadir viewing geometry and the ATMOS, MIPAS, SMR, ACE and MLS (Barret et al., 2006; Clerbaux et al., 2008; Funke et al., 2007; Rinsland et al., 2000; Pumphrey et al., 2007) instruments with a limb viewing geometry. Ethane concentrations have been retrieved previously by MIPAS and ACE (Glatthor et al., 2009; Rinsland et al., 2005) from enhanced concentrations in biomass burning plumes. So far, ethyne has been retrieved extensively from space by ACE, for example as reported by Park et al. (2008) in the Asian monsoon anticyclone and by MIPAS (Glatthor et al., 2007; Parker et al., 2010) some more limited retrievals were made previously by ATMOS for both ethane and ethyne (Irion et al., 2002).

Concentrations of these molecules have been retrieved using data from the ACE Fourier Transform Spectrometer (FTS) and compared with aircraft data from the GTE (Global Tropospheric Experiment) TRACE-A (Transport and Atmospheric Chemistry near the Equator-Atlantic) field mission (Blake et al., 1996; Chatfield et al., 1998; Fishman et al., 1996) and from the MkIV balloon-borne FTIR flights near Fort Sumner (Toon, 1991). A detailed discussion of these comparisons will show that ACE retrieved concentrations are in good agreement with correlative measurements.

In addition, we compare the ACE measurements with carbon monoxide, ethane and ethyne concentrations simulated by the GEOS-Chem chemical transport model (Bey et al., 2001). In these comparisons seasonal variations and hemispheric asymmetries observed with ACE data are reproduced with good accuracy by the model output. The structure of the paper is as follows. Section two includes a description of the ACE-FTS and the retrieval process for carbon monoxide, ethane and ethyne as well as the data subset used in the paper. We will analyze the errors in the retrieval process for ethane and ethyne. The ACE CO product has been validated extensively so we simply cite the previous work (Clerbaux et al., 2008). In section three the retrieved ACE concentrations will be compared with TRACE-A and MkIV data. The fourth section is focused on the GEOS-Chem model in which the set up of the model used in this paper is explained and discussed. In section five the data from ACE and GEOS-Chem are analyzed, discussed and compared; the final section is a conclusion.

\section{ACE-FTS measurements and data}

The ACE-FTS (Atmospheric Chemistry Experiment-Fourier Transform Spectrometer) is the main instrument on board the Canadian satellite SCISAT-1 launched by NASA in August 2003 (see http://www.ace.uwaterloo.ca/). Working primarily in solar occultation with a resolution of $0.02 \mathrm{~cm}^{-1}$ in the 2.2 to $13.3 \mu \mathrm{m}\left(750-4400 \mathrm{~cm}^{-1}\right)$ spectral range, the instrument provides altitude profile information for temperature, pressure and volume mixing ratios (VMRs) for numerous molecules of atmospheric interest between $85^{\circ} \mathrm{N}$ and $85^{\circ} \mathrm{S}$ (Bernath et al., 2005).

The CO retrievals reported in this paper are the standard version 2.2 set of the ACE-FTS retrievals (Boone et al., 2005) using the same linelist that was used by Clerbaux et al. (2008). We use the first overtone of CO when the fundamental lines become saturated allowing us to retrieve $\mathrm{CO}$ concentrations down to $5 \mathrm{~km}$.

The $\mathrm{C}_{2} \mathrm{H}_{6}$ and $\mathrm{C}_{2} \mathrm{H}_{2}$ are a research version based in the same global-fit coupled with a Lenvenberg-Marquardt nonlinear least-square algorithm used in the version 2.2 of the ACE-FTS data (Boone et al., 2005). Pressure and temperatures used in the retrieval are from version 2.2. $\mathrm{C}_{2} \mathrm{H}_{6}$ retrievals use the ${ }^{\mathrm{P}} \mathrm{Q}_{3}$ branch in the $v_{7}$ band located around $3 \mu \mathrm{m}$. A $2 \mathrm{~cm}^{-1}$ microwindow centred at $2976.5 \mathrm{~cm}^{-1}$ has been used. The retrieval altitude range is between 5 and $20 \mathrm{~km}$. Interferers in this microwindow are $\mathrm{H}_{2} \mathrm{O}, \mathrm{H}^{18} \mathrm{OH}$, $\mathrm{O}_{3}, \mathrm{CH}_{4}$ and $\mathrm{CH}_{3} \mathrm{D}$ with VMR profiles retrieved for each of these isotopologues. Figure 1 shows, as an example, synthetic spectra calculated with the forward model, the observed spectra and the residuals with and without ethane included in the forward model. The reduction of the residuals 

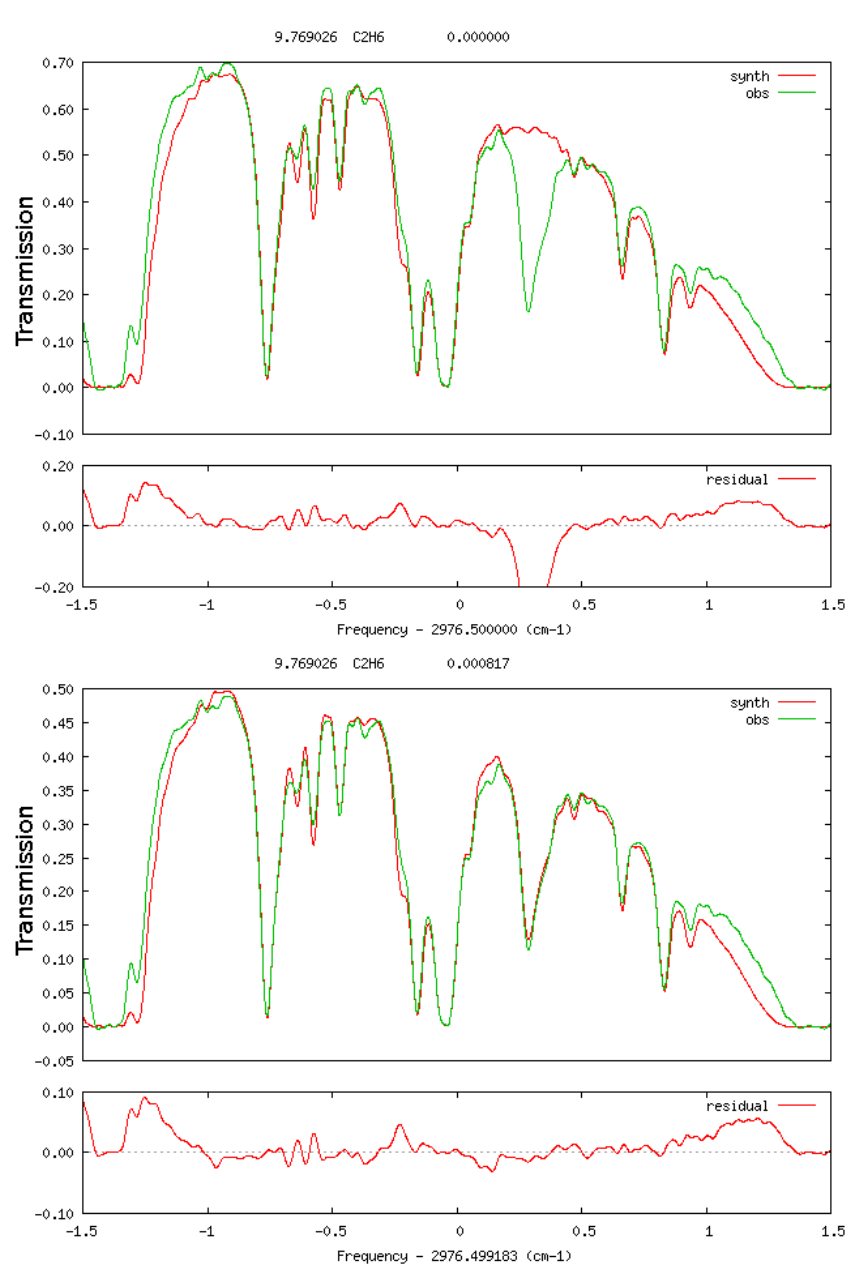

Fig. 1. Calculated spectrum, observed spectrum and residuals for occultation ss 11613 at $9.76 \mathrm{~km}$. Top panel shows a calculated spectrum without the $\mathrm{C}_{2} \mathrm{H}_{6}$ contribution. In the residual plot we can observe the feature due to the absence of $\mathrm{C}_{2} \mathrm{H}_{6}$ in the forward model.

when ethane is included in the forward model shows the viability of the retrieval in this microwindow.

$\mathrm{C}_{2} \mathrm{H}_{2}$ retrievals use the $v_{3}$ and $v_{2}+v_{4}+v_{5}$ bands in the $3 \mu \mathrm{m}$ region. A complete list of the fourteen microwindows used for its retrieval is reported in Table 1. As stated above this selection of microwindows improves the retrieval in comparison with previous versions of the ACE ethyne product. The new ACE version 3.0 ethyne product makes use of these microwindows. The retrieval altitude range extends between 5 and $15 \mathrm{~km}$. Interferers for the retrieval of ethyne are $\mathrm{H}_{2} \mathrm{O}, \mathrm{H}^{18} \mathrm{OH}, \mathrm{H}^{17} \mathrm{OH}, \mathrm{N}_{2} \mathrm{O}, \mathrm{CO}_{2}, \mathrm{C}^{13} \mathrm{OO}, \mathrm{C}^{18} \mathrm{OO}, \mathrm{O}_{3}$ and $\mathrm{HCN}$. The spectroscopic data used for the retrieval of all three molecules is in the HITRAN 2004 database (Rothman et al., 2005). The errors associated with the CO retrievals have been reported previously to be smaller than $2 \%$ (Clerbaux et al., 2005). The errors for $\mathrm{C}_{2} \mathrm{H}_{6}$ and $\mathrm{C}_{2} \mathrm{H}_{2}$ in a typical VMR profile are dominated by statistical errors. For ethane the errors are usually between $30 \%$ in tropical regions and

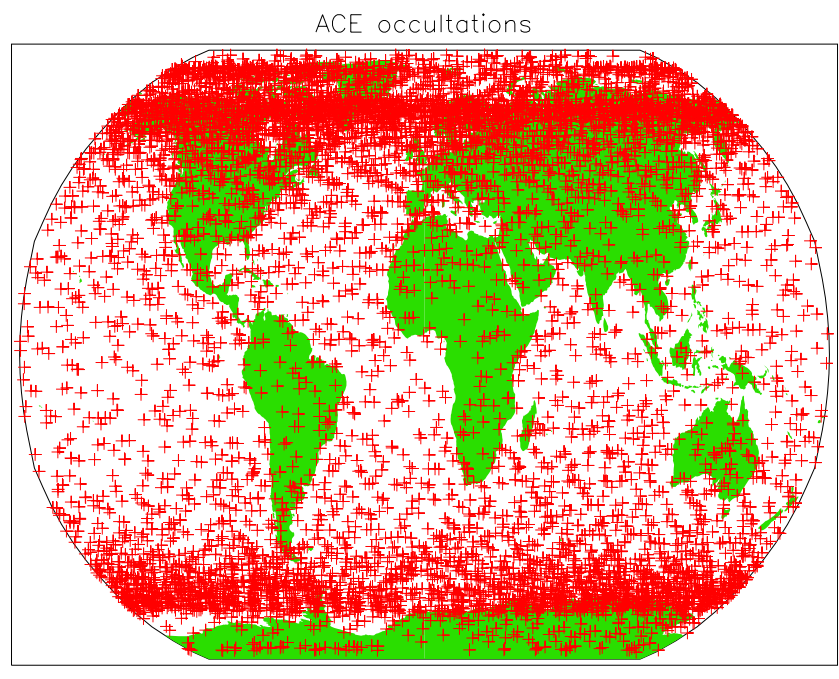

Fig. 2. ACE extravortex occultations between January 2004 and February 2007.

improve to $20 \%$ towards the poles. Ethyne errors are less than $25 \%$ near the North Pole and less than $30 \%$ near the South Pole increasing towards the equator and with altitude. A more detailed analysis of the retrieval error for these two molecules is to follow in Sect. 2.1.

About 11000 occultations recorded between January 2004 and February 2007 have been used in this study. We have used the DMPs (Derived Meteorological Products) (Manney et al., 2007) to filter out data within or at the edge of the polar vortex (Nassar et al., 2005). 8200 occultations remain for the study after applying the polar vortex filter. The inclination of the SCISAT- 1 orbit ( $74^{\circ}$ to the equator) (Bernath, 2006) provides a large number of occultations at high latitudes therefore we decided to discard the occultations perturbed by the descent of the cold, isolated air in the polar vortex. The locations of the occultations used are plotted in Fig. 2. Note that there is an uneven distribution of data, with many occultations available near the poles and just a few hundred in tropical regions.

\section{$2.1 \quad \mathrm{C}_{2} \mathrm{H}_{6}$ and $\mathrm{C}_{2} \mathrm{H}_{2}$ retrieval error analysis}

Error analysis of VMRs retrieved by ACE-FTS has to consider two components: the statistical or random error and the systematic error. The statistical part of the error corresponds to the error provided by the fitting algorithm (Boone et al., 2005). The $1 \sigma$ error for the state variable $x_{j}$ in a LevenbergMarquardt fitting algorithm is:

$\sigma_{m}\left(x_{j}\right)=\sqrt{\left(\mathbf{K}^{T} \mathbf{S}_{y}^{-1} \mathbf{K}\right)_{j j}^{-1}}$

where $\mathbf{K}$ is the Jacobian of the forward model and $\mathbf{S}_{y}$ is the covariance matrix of the measurements, assumed to be diagonal. This error, often called measurement noise is plotted in 
Table 1. Microwindows used for the retrieval of $\mathrm{C}_{2} \mathrm{H}_{2}$ in this paper.

\begin{tabular}{cccc}
\hline $\begin{array}{c}\text { Centre wavenumber } \\
\left(\mathrm{cm}^{-1}\right)\end{array}$ & $\begin{array}{c}\text { Microwindow width } \\
\left(\mathrm{cm}^{-1}\right)\end{array}$ & $\begin{array}{c}\text { Lower altitude } \\
(\mathrm{km})\end{array}$ & $\begin{array}{c}\text { Upper altitude } \\
(\mathrm{km})\end{array}$ \\
\hline 3268.30 & 0.80 & $8-3 \mid\left.\sin ($ latidude $)\right|^{2}$ & 20 \\
3270.20 & 1.00 & $12-4 \mid\left.\sin ($ latidude $)\right|^{2}$ & 20 \\
3278.45 & 1.00 & $14-2 \mid\left.\sin ($ latidude $)\right|^{2}$ & 20 \\
3286.00 & 1.60 & $12-4 \mid\left.\sin ($ latidude $)\right|^{2}$ & 20 \\
3287.45 & 0.90 & $10-3 \mid\left.\sin ($ latidude $)\right|^{2}$ & 20 \\
3295.90 & 0.80 & $10-3 \mid \sin$ (latidude $)\left.\right|^{2}$ & 20 \\
3300.40 & 0.80 & $15-3 \mid \sin$ (latidude $)\left.\right|^{2}$ & 20 \\
3304.60 & 1.30 & $10-4 \mid \sin$ (latidude $)\left.\right|^{2}$ & 20 \\
3304.95 & 0.80 & $8-3 \mid \sin$ (latidude $)\left.\right|^{2}$ & $10-4 \mid\left.\sin ($ latidude $)\right|^{2}$ \\
3315.98 & 0.85 & $8-3 \mid \sin$ (latidude $)\left.\right|^{2}$ & 20 \\
3317.05 & 0.60 & $14-4 \mid \sin$ (latidude $)\left.\right|^{2}$ & 20 \\
3322.05 & 1.00 & 10 & 20 \\
3331.40 & 0.80 & $8-3 \mid \sin$ (latidude) $\left.\right|^{2}$ & 20 \\
3335.57 & 0.45 & $9-3 \mid \sin$ (latidude) $\left.\right|^{2}$ & 20 \\
\hline
\end{tabular}

Figs. 3 and 4 in orange for the average of 25 representative occultations selected for the error analysis.

Analysis of systematic errors needs to be considered to quantify the effect of the variability of important parameters in the retrieval algorithm. Systematic errors are caused by the uncertainty of relevant parameters $\left(b_{j}\right)$ in the retrieval process. The effects of these uncertainties in the retrieved VMRs $\left(\Delta x_{j}\right)$ have been quantified using:

$\Delta x_{j}=\left|x\left(b_{j}\right)-x\left(b_{j}+\Delta b_{j}\right)\right|$

where $x\left(b_{j}\right)$ is the standard retrieved VMR and $x\left(b_{j}+\Delta b_{j}\right)$ is the retrieved VMR after perturbation of the relevant parameter $\left(b_{j}\right)$ in the retrieval process. The relevant parameters have been perturbed by $1 \sigma$ of its assumed uncertainty, one at a time while keeping the others unchanged. The relevant parameters considered and their $1 \sigma$ uncertainties are: temperature $(2 \mathrm{~K})$, tangent height $(150 \mathrm{~m})$, instrumental line shape (5\% of field of view) (Dufour et al., 2009), mixing ratio uncertainties of the main interferers, $10 \%$ for $\mathrm{H}_{2} \mathrm{O}, 1 \%$ for $\mathrm{CO}_{2}, 5 \%$ for $\mathrm{O}_{3}$ and $25 \%$ for $\mathrm{N}_{2} \mathrm{O}$ (McHugh et al., 2005) and spectroscopic data uncertainties assumed to be $5 \%$ for $\mathrm{C}_{2} \mathrm{H}_{2}$ (Rothman et al., 2005) and $10 \%$ for $\mathrm{C}_{2} \mathrm{H}_{6}$. A restricted subset of 25 occultations covering all latitudes and seasons has been selected for this analysis. The effective total error is calculated as the root mean square (RMS) of the sum of the statistical error and the systematic error components.

Figures 3 and 4 summarize the impact of the different parameters on the quality of the retrieval. In general the perturbation of these parameters has a relatively small impact on the retrieved VMRs of ethane and ethyne with changes less than $5 \%$ for all of them. Only the perturbation of the tangent height causes a change in the retrieved VMRs which is big enough to change the effective error, at altitudes above
$9 \mathrm{~km}$ in the case of $\mathrm{C}_{2} \mathrm{H}_{6}$ and over the full range of altitudes for $\mathrm{C}_{2} \mathrm{H}_{2}$. The effective error for $\mathrm{C}_{2} \mathrm{H}_{6}$ is between $20 \%$ and $30 \%$ over the $6 \mathrm{~km}$ to $12 \mathrm{~km}$ altitude range increasing to $40 \%$ for altitudes between $12 \mathrm{~km}$ and $14 \mathrm{~km}$. At higher altitudes the random error increases sharply due to the low atmospheric concentrations of ethane, near the limits of the retrieval. For $\mathrm{C}_{2} \mathrm{H}_{2}$ the effective error is slightly larger than for $\mathrm{C}_{2} \mathrm{H}_{6}$. Ethyne errors at altitudes below $10 \mathrm{~km}$ are less than $30 \%$ and increase to values between $40 \%$ and $50 \%$ for the altitude range between $10 \mathrm{~km}$ and $14 \mathrm{~km}$. This error analysis shows that the VMRs errors are mainly dominated by the random component of the error with a small systematic error component caused mainly by uncertainties in the knowledge of the tangent height. Errors for single profiles are generally less than $30 \%$ in the troposphere for both molecules.

\section{Balloon and aircraft comparisons}

We have compared our retrieved concentrations with those obtained by a similar instrument, the MkIV FTS, and with concentrations obtained with in situ instruments deployed on the DC-8 aircraft in the TRACE-A field campaign. The MkIV-FTS records solar occultation spectra from a high altitude balloon in the $650-5640 \mathrm{~cm}^{-1}$ spectral range with a spectral resolution of $0.01 \mathrm{~cm}^{-1}$ (Toon, 1991). MkIV data obtained in five flights carried out from Ft. Sumner, New Mexico $\left(34.4^{\circ} \mathrm{N}, 104.2^{\circ} \mathrm{W}\right)$ during September 2003, 2004, 2005 and 2007 have been compared with the ACEFTS retrievals. These flights took place during the autumn turn-around period when the stratospheric winds are light enough to permit long duration $(15-30 \mathrm{~h})$ flights. The VMR retrievals extend from the cloud tops up to the float 

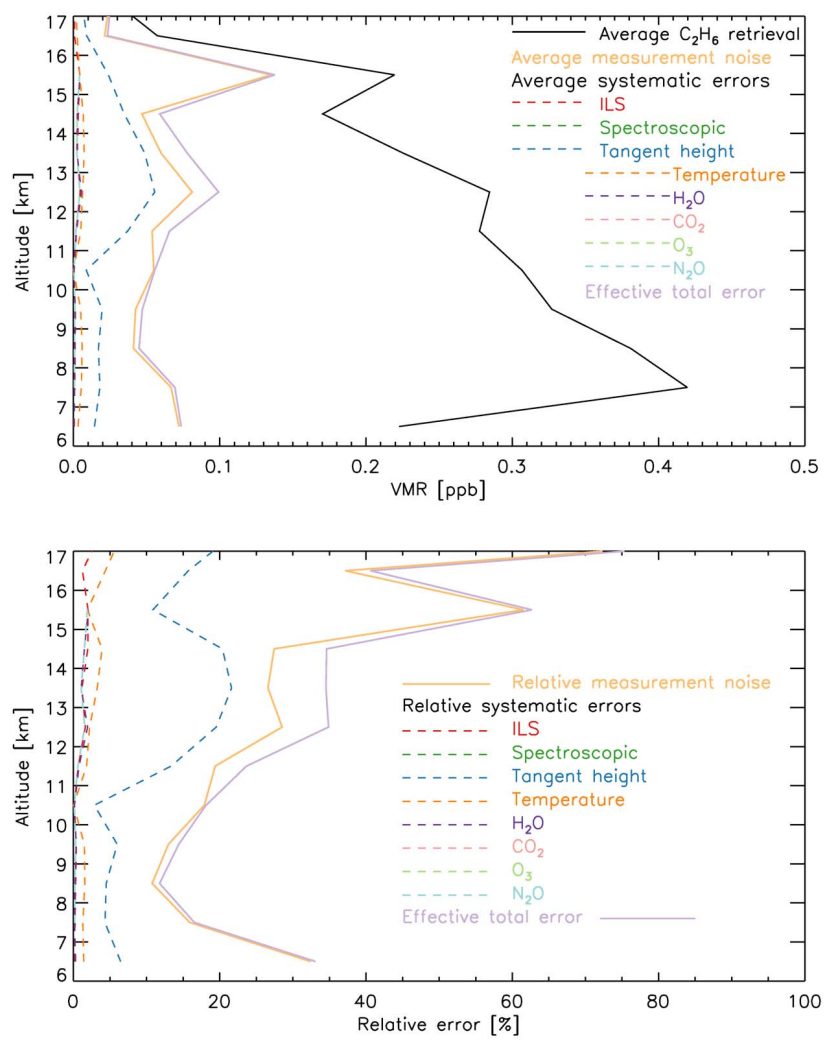

Fig. 3. Top panel: Mean VMR profile of $\mathrm{C}_{2} \mathrm{H}_{6}$ (black) for the 25 occultations selected for the error budget calculations and the absolute value of the contribution of each component. Lower panel: Relative contribution of each of the components considered in the error budget calculation. In purple in both panels is the effective total error.

altitude (typically $38 \mathrm{~km}$ ) with $2-3 \mathrm{~km}$ vertical resolution. The MkIV retrieval used the JPL retrieval code GFIT (Sen et al., 1998). Figure 5 shows the result of this comparison between MkIV-FTS and ACE-FTS retrievals. Only ACE occultations within the same time period of the year (September, October, November) and within latitudes and longitudes similar to Ft. Sumner have been used to carry out these comparisons. Very few ACE occultations are near New Mexico and for this reason an average of occultations from the continental USA $\left(30^{\circ} \mathrm{N}-54^{\circ} \mathrm{N}\right.$ and $\left.85^{\circ} \mathrm{W}-115^{\circ} \mathrm{W}\right)$ for the fall season has been used.

Below $11 \mathrm{~km}$, only one MkIV occultation is available making the assessment of the MkIV measured concentration variability impossible below this altitude. The pollution plume shape of the ACE average concentrations, with enhancements of all three molecules below $11 \mathrm{~km}$, introduces another difficulty in the comparison since the observed MkIV plume does not show such enhancements. Above $11 \mathrm{~km}$, MkIV CO shows a consistent positive bias respect to ACE values but the shapes of both profiles are similar. For $\mathrm{C}_{2} \mathrm{H}_{6}$ the comparison shows some of the MkIV values within one
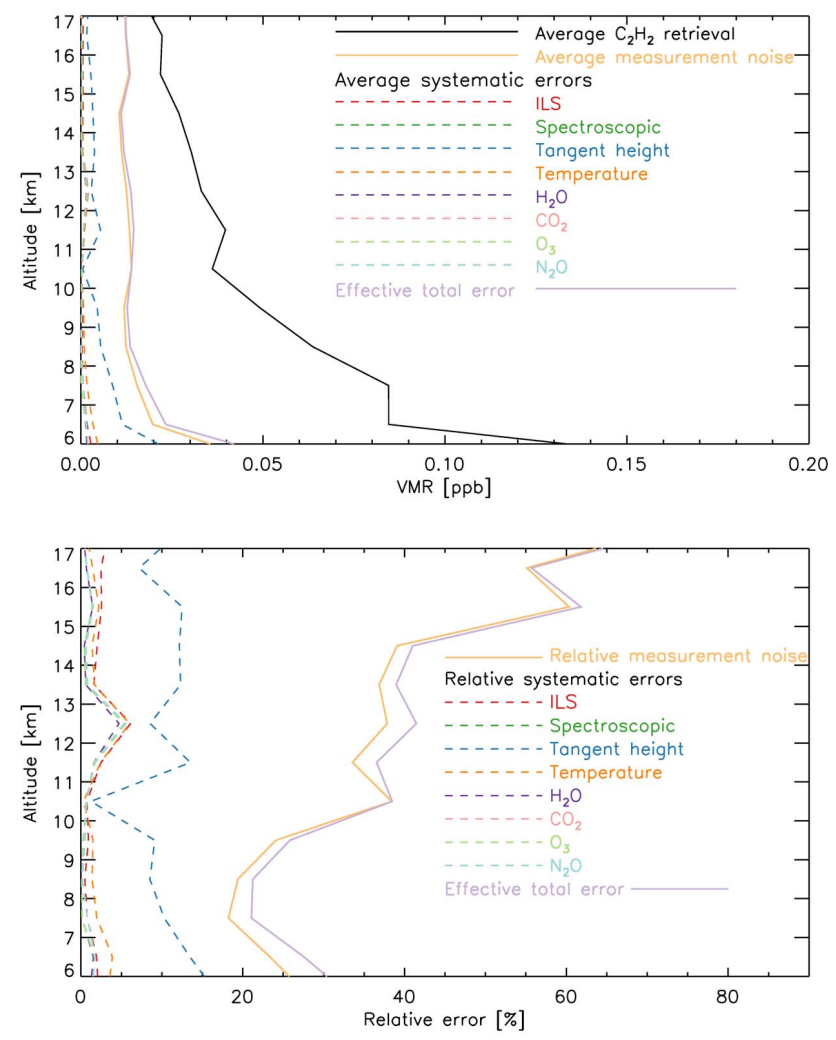

Fig. 4. Top panel: Mean VMR profile of $\mathrm{C}_{2} \mathrm{H}_{2}$ (black) for the 25 occultations selected for the error budget calculations and the absolute value of the contribution of each component. Lower panel: Relative contribution of each of the components considered in the error budget calculation. In purple in both panels is the effective total error.

standard deviation of the ACE average profile. Finally for $\mathrm{C}_{2} \mathrm{H}_{2}$ the situation is slightly different because the ACE average profile is between two groups of MkIV occultations. The comparison of these two datasets is only useful above $11 \mathrm{~km}$ whereas below this altitude the lack of MkIV measurements makes it inconsistent. However, the comparison of ACE data with the TRACE-A aircraft data, discussed below, provides valuable information for altitudes below $11 \mathrm{~km}$.

The TRACE-A field campaign aircraft flights took place between 21 September and 24 October 1992. The flights were located around $12^{\circ} \mathrm{S}$ and between $40^{\circ} \mathrm{E}$ and $70^{\circ} \mathrm{W}$ (Blake et al., 1996; Fishman et al., 1996) and only ACEFTS occultations situated near this location and occurring in the same season have been used to compare with the aircraft data. Figure 6 shows carbon monoxide, ethane and ethyne concentrations from the TRACE-A measurements and the ACE-FTS. Values from satellite and aircraft are in good agreement with aircraft concentrations falling within one standard deviation of the average satellite values. 

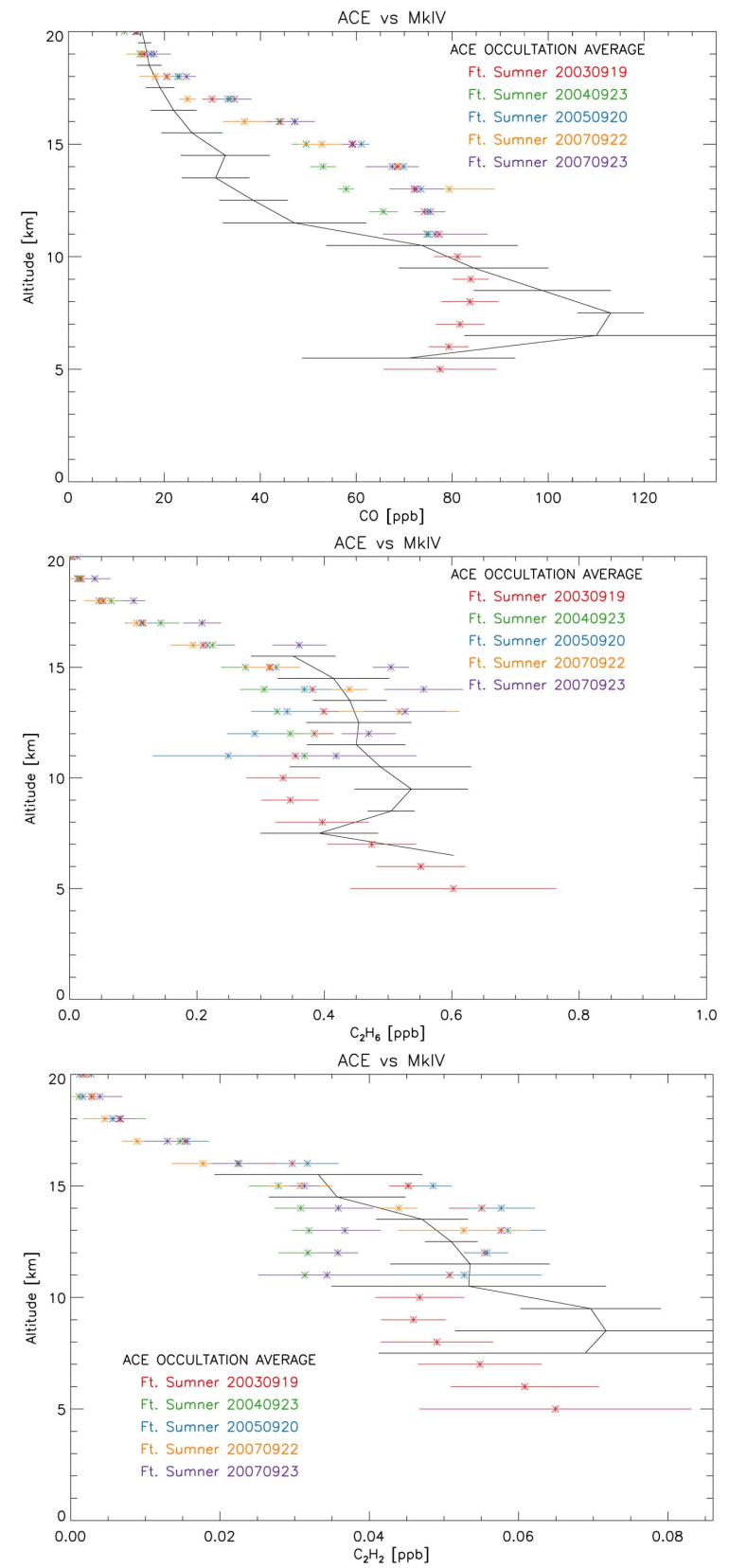

Fig. 5. Comparison of ACE-FTS average profile and MkIV-FTS profiles. Top panel CO, middle panel $\mathrm{C}_{2} \mathrm{H}_{6}$ and lower panel $\mathrm{C}_{2} \mathrm{H}_{2}$.

The MkIV and TRACE-A correlative comparisons show that the concentrations retrieved using ACE spectra are generally reliable in the upper troposphere and lower stratosphere region.

\section{GEOS-Chem}

GEOS-Chem version v8-02-03 (http://acmg.seas.harvard. edu/geos/) is a global 3-D chemical transport model able to simulate trace gases and aerosol distributions in the tropo-
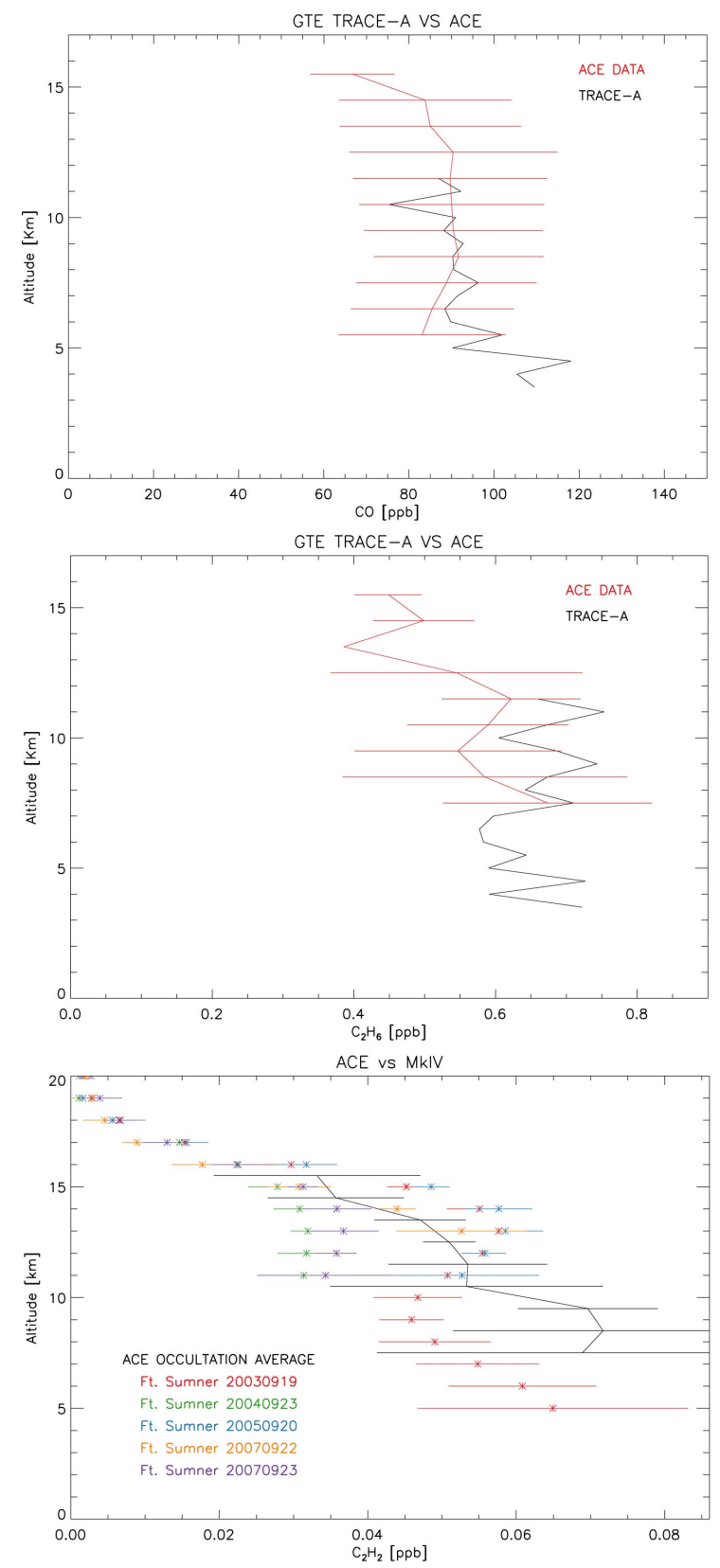

Fig. 6. Comparison of ACE-FTS average profiles and GTE, TRACE-A aircraft field campaign concentrations of $\mathrm{CO}$, top panel, $\mathrm{C}_{2} \mathrm{H}_{6}$ middle panel and $\mathrm{C}_{2} \mathrm{H}_{2}$ lower panel.

sphere (Bey et al., 2001). The model is driven by assimilated meteorological observations from the Goddard Earth Observing System (GEOS) of the NASA Global Modelling and Assimilation Office (GMAO). We have used here the GMAO GEOS-5 operational meteorology data. GEOS-5 meteorological fields have a temporal resolution of $6 \mathrm{~h}(3 \mathrm{~h}$ for surface variables), a horizontal resolution of $0.5^{\circ}$ latitude by $0.667^{\circ}$ longitude and a vertical resolution of 72 eta hybrid levels extending from the surface up to $0.01 \mathrm{hPa}$. The 
resolution of these meteorological data is degraded for model input to a horizontal resolution of $4^{\circ}$ latitude by $5^{\circ}$ longitude and with vertical resolution reduced to 47 eta levels by collapsing levels above $\sim 80 \mathrm{hPa}$ into groups of 2 or 4 layers.

For this paper we need the model predictions for ethyne, ethane and carbon monoxide with the appropriate spatial and temporal resolution. Twenty four hour average concentrations have been considered in this paper given the lifetimes of the molecules. Since the satellite data have a very uneven geographical and temporal distribution only model data coincident in time, average of a given day, and space with each ACE occultation has been used. The GEOS-Chem data have been interpolated to the satellite altitude grid of $1 \mathrm{~km}$ resolution.

The GEOS-Chem chemical mechanism used in this study is the standard NOx-Ox-Hydrocarbon-Aerosol simulation (Horowitz et al., 1998; Martin et al., 2003) with the dicarbonyls chemistry extension (Fu et al., 2008) in order to include explicit ethyne chemistry and updated VOCs including aromatics and dicarbonyls. The main sink for ethane is oxidation with $\mathrm{OH}$. Another minor ethane sink included in the model is oxidation by $\mathrm{NO}_{3}$. Ethyne oxidation with $\mathrm{OH}$ is the only sink included in the model for this species.

Carbon monoxide and ethane emissions include anthropogenic emissions based in the Global Emission Inventory Activity (GEIA) (Wang et al., 1998) for ethane and in the Emission Database for Global Atmospheric Research (EDGAR) for carbon monoxide. Scaling factors have been used to scale the emissions to present-day values. Updates with regional inventories are used where available: The European Monitoring and Evaluation Programme (EMEP) for Europe (Auvray and Bey, 2005) designed for the year 2005, the Big Bend Regional Aerosol and Visibility Observational (BRAVO) Study Emissions Inventory for Mexico (Kuhns et al., 2005) designed for the year 1999, the Streets inventory for South East Asia (Zhang et al., 2009) with base years 2000, 2004 and 2006, the Criteria Air Contaminant inventory (CAC) over Canada with 2002 and 2005 base years and the Environmental Protection Agency/National Emission Inventory (EPA/NEI) (Hudman et al., 2008) for USA with base years 1999 and 2004. Biofuel emissions of $\mathrm{CO}$ and $\mathrm{C}_{2} \mathrm{H}_{6}$ are included in the model (Yevich and Logan, 2003) as well as biomass burning emissions from the monthly data of the Global Fire Emission Database version 2 (GFEDv2) (Giglio et al., 2006). For $\mathrm{C}_{2} \mathrm{H}_{2}$ biomass burning emissions, anthropogenic emissions and biofuel emissions the model uses the approach followed by Xiao et al. (2007) based on emission factors of ethyne relative to CO. Using this set up for the emissions the following total global budgets are produced by GEOS-Chem. For carbon monoxide for the year 2005 the total emission budget is $1178 \mathrm{Tg}$ with $340 \mathrm{Tg}$ contribution of anthropogenic origin, $173 \mathrm{Tg}$ from biofuel emissions, $610 \mathrm{Tg}$ due to biomass burning and $53 \mathrm{Tg}$ from monoterpene oxidation. The ethane budget for 2005 is $12 \mathrm{TgC}(15 \mathrm{Tg})$ with 7.5 Tg C having an anthropogenic origin, $2 \mathrm{Tg} \mathrm{C}$ from biofuel and $2.5 \mathrm{Tg} \mathrm{C}$ from biomass burning. Finally the ethyne budget is $5 \mathrm{TgC}$ with $1.25 \mathrm{TgC}$ having an anthropogenic origin, $2.75 \mathrm{Tg} C$ produced due to the usage of biofuel and $1.25 \mathrm{Tg} \mathrm{C}$ coming from biomass burning. Figs. S1, S2 and S3 (Supplement) show a global map with the total emissions for each molecule.

We have run the model between February 2004 and February 2007, the period of time for which ACE-FTS data was available for this study. The model was spun-up with a 3 month run from November 2003 before restarting it in February 2004.

\section{ACE-FTS and GEOS-Chem data analysis and comparison}

Figure 7 shows ACE data available at $7.5 \mathrm{~km}$ altitude for all three molecules during the period between February 2004 and February 2007. The hotspots are due to biomass burning plumes (Tereszchuk et al., 2011) and high anthropogenic emissions. Concentrations as high as $250 \mathrm{ppb}$ for $\mathrm{CO}, 2.50 \mathrm{ppb}$ for $\mathrm{C}_{2} \mathrm{H}_{6}$ and $0.5 \mathrm{ppb}$ for $\mathrm{C}_{2} \mathrm{H}_{2}$ are observed at $6.5 \mathrm{~km}$, which is usually the lowest altitude retrieved. However, a number of occultations have retrievals at $5.5 \mathrm{~km}$. The average profiles obtained for the entire period of study are available in supplementary Tables $\mathrm{S} 1, \mathrm{~S} 2$ and $\mathrm{S} 3\left(\mathrm{CO}, \mathrm{C}_{2} \mathrm{H}_{6}\right.$ and $\mathrm{C}_{2} \mathrm{H}_{2}$ respectively) and altitude-latitude cross sections are shown in supplementary Fig. S4 (Supplement). The hemispherical asymmetry of concentrations in the middle and upper troposphere with higher values in the Northern Hemisphere is observed in this figure for all three molecules.

The horizontal resolution used for the model simulations is $4^{\circ}$ latitude by $5^{\circ}$ longitude and therefore the grid is roughly $330 \mathrm{~km}$ by $640 \mathrm{~km}$. This allows us to compare it with the $500 \mathrm{~km}$ horizontal resolution ACE data (Sica et al., 2008). ACE data above the tropopause have been discarded for the comparison between the model and the satellite using the information available in the DMPs (Manney et al., 2007). After the collocation the data have been averaged in $10^{\circ}$ latitude bins and into temporal seasons for the period February 2004 to February 2007. December-JanuaryFebruary 2004-2005 (DJF0405), March-April-May 2005 (MAM05), June-July-August 2005 (JJA05) and SeptemberOctober-November 2005 (SON05) are selected to carry out a more detailed study due to the substantial amount of ACE data available during 2005.

Figure 8 shows the altitude-latitude cross sections for $\mathrm{CO}$. We clearly see the hemispherical asymmetry and the seasonal variation of $\mathrm{CO}$ concentrations in the upper and middle troposphere linked mainly to anthropogenic emissions and biomass burning seasons over South America, Africa and boreal regions. High concentrations of $\mathrm{CO}$ in the Southern Hemisphere (SON season) are linked to biomass burning episodes. This is the strongest feature for CO in Southern latitudes and the model underestimates it, simulating 

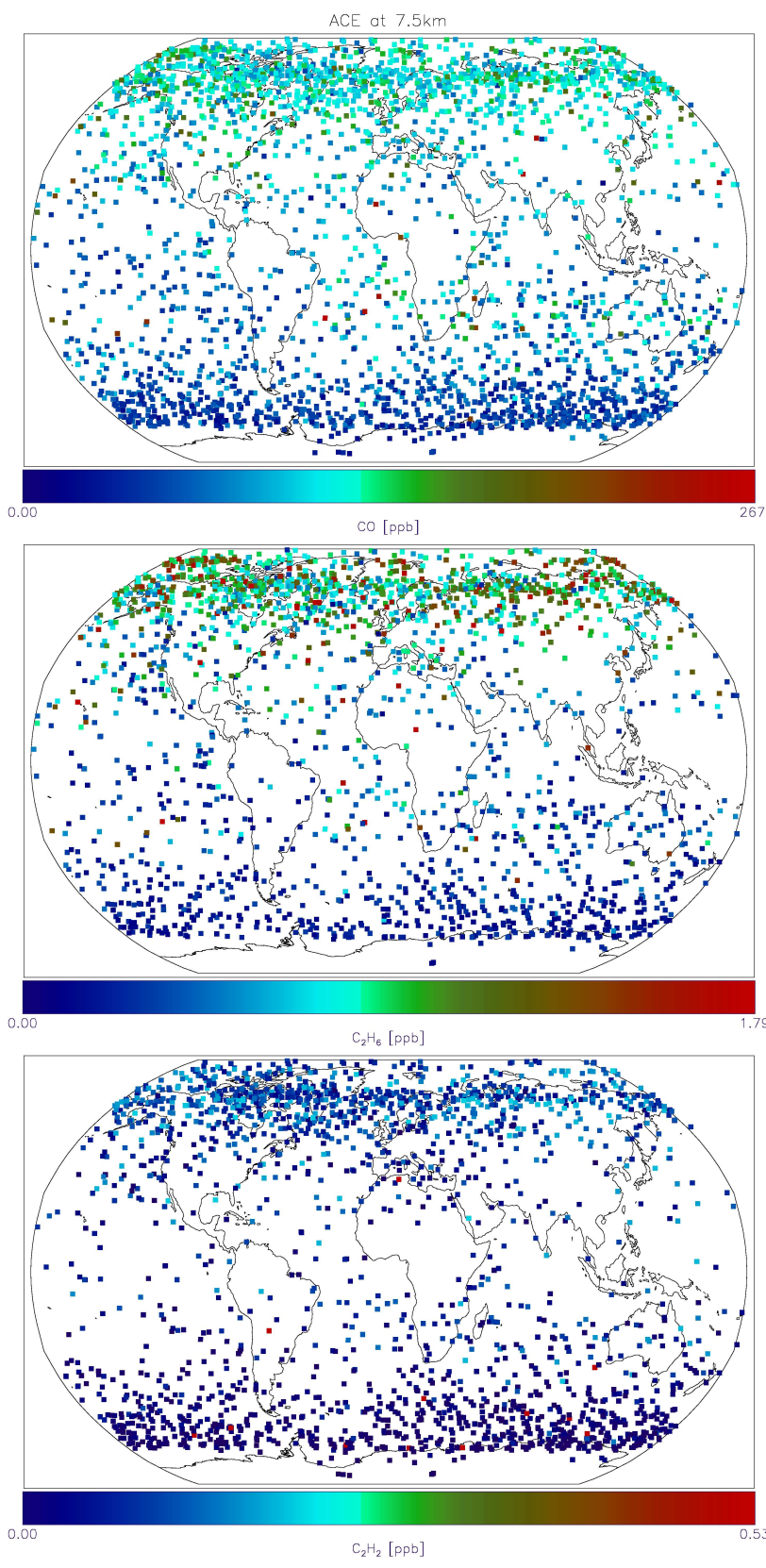

Fig. 7. $\mathrm{CO}, \mathrm{C}_{2} \mathrm{H}_{6}$ and $\mathrm{C}_{2} \mathrm{H}_{2}$ concentrations at $7.5 \mathrm{~km}$ retrieved using ACE-FTS spectra during the period between February 2004 and February 2007. Top panel CO, middle panel $\mathrm{C}_{2} \mathrm{H}_{6}$ and bottom panel $\mathrm{C}_{2} \mathrm{H}_{2}$.

concentrations around $17 \%$ lower than the satellite retrieved concentrations for the SON fire season. However the model overestimates the concentrations over Antarctica and the rest of the Southern Hemisphere in DJF and MMA. Two implications can be extracted from this observation: first the model underestimates the biomass burning emissions and second in general the $\mathrm{OH}$ removal mechanism is not efficient enough. In the Northern Hemisphere the biomass emissions do not

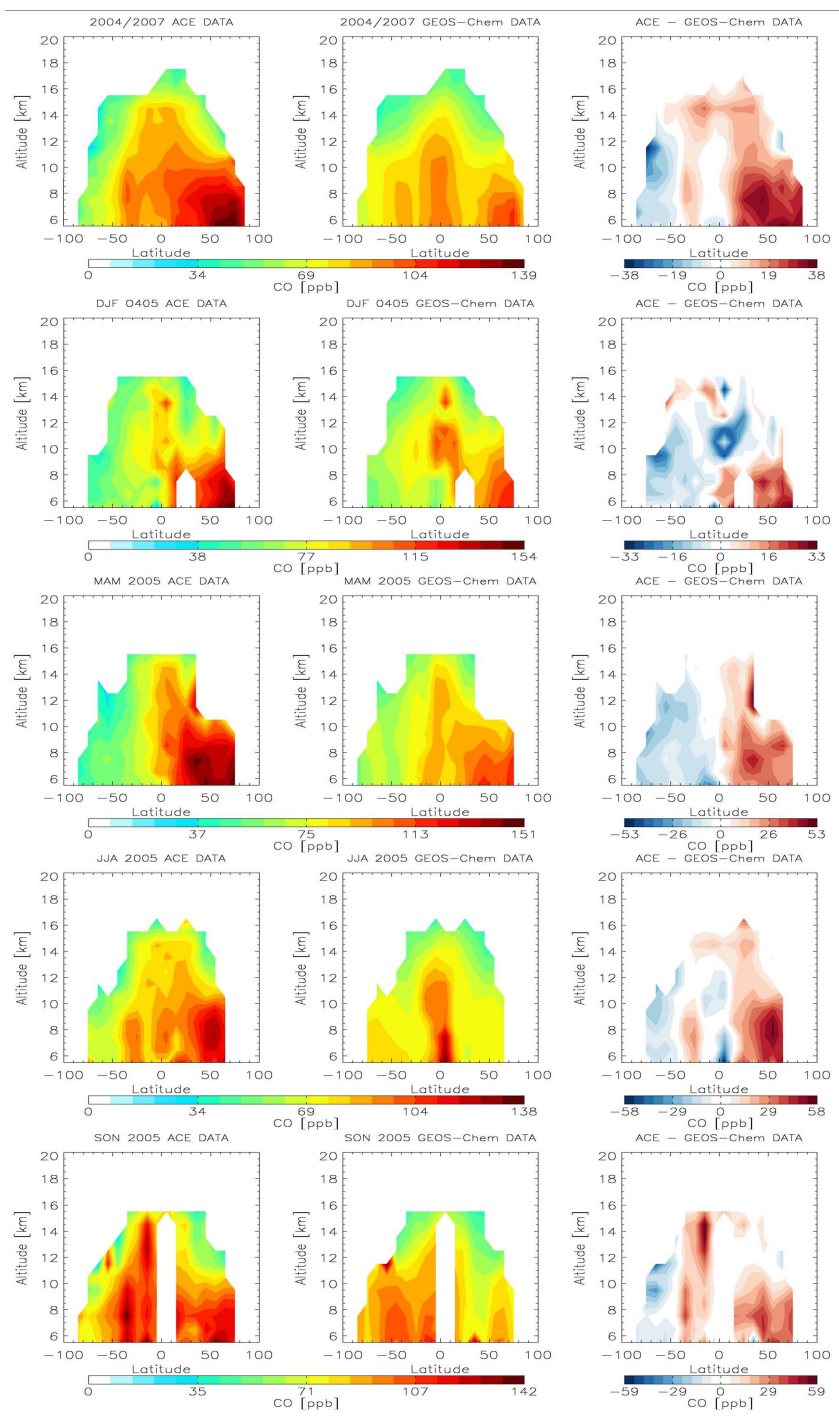

Fig. 8. CO altitude-latitude cross sections from ACE (left column), GEOS-Chem (central column) and difference between both data sets (right column). Top panel 2004-2007 time period, second panel December-January-February 2004/2005, third panel March-AprilMay 2005, fourth panel June-July-August 2005 and fifth panel September-October-November 2005.

have such a strong impact on tropospheric CO concentrations and anthropogenic emissions are dominant. The seasonal variation is therefore not as strong as in the Southern Hemisphere and this can be observed clearly in the ACE data (Clerbaux et al., 2008). Although GEOS-Chem is able to capture this feature, it underestimates $\mathrm{CO}$ concentrations in the Northern Hemisphere (Kopacz et al., 2010) by $15 \%$. The hemispheric asymmetry is also well represented by the model.

Ethane altitude-latitude cross sections are presented in Fig. 9. Once again the seasonal variation and the hemispheric asymmetry are well simulated by the model. Human 


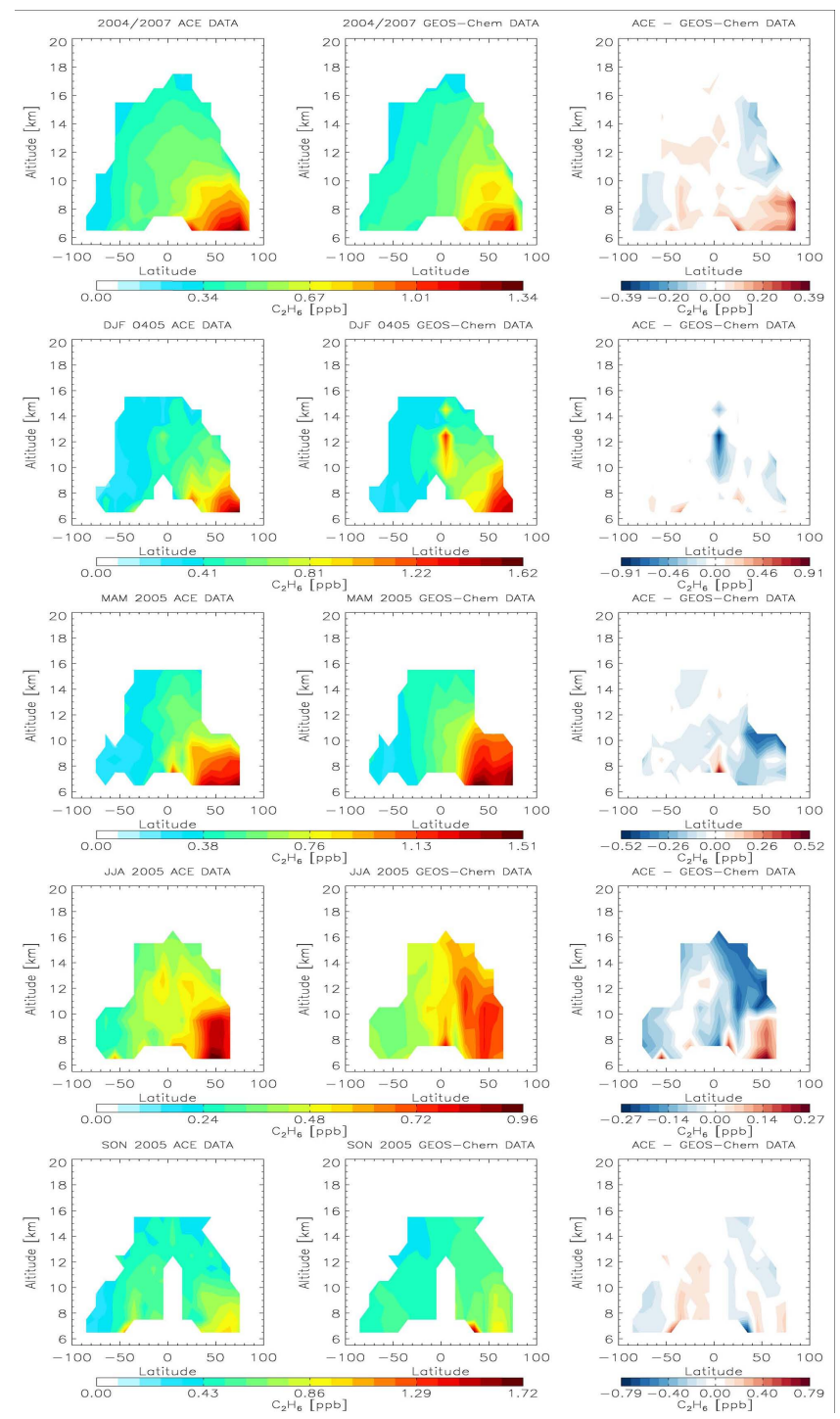

Fig. 9. $\mathrm{C}_{2} \mathrm{H}_{6}$ altitude-latitude cross sections from ACE left column, GEOS-Chem central column and difference between both data sets right column. Top panel full study time period, second panel December-January-February 2004/2005, third panel March-AprilMay 2005, fourth panel June-July-August 2005 and fifth panel September-October-November 2005.

activity is the main reason for the hemispheric asymmetry and biomass burning emissions contribute strongly to the seasonal variation in both Hemispheres. The first results obtained for ethane from the model showed an unrealistic high positive bias in the Southern Hemisphere, which led us to fix a small bug in the $\mathrm{C}_{2} \mathrm{H}_{6}$ emissions over Africa. Emission factors were unrealistically large over Namibia leading to anomalously high emissions. It was estimated that the emissions were two orders of magnitude bigger than what they should be. Therefore to give the ethane model output a more reasonable value, emissions were reduced by $99 \%$.

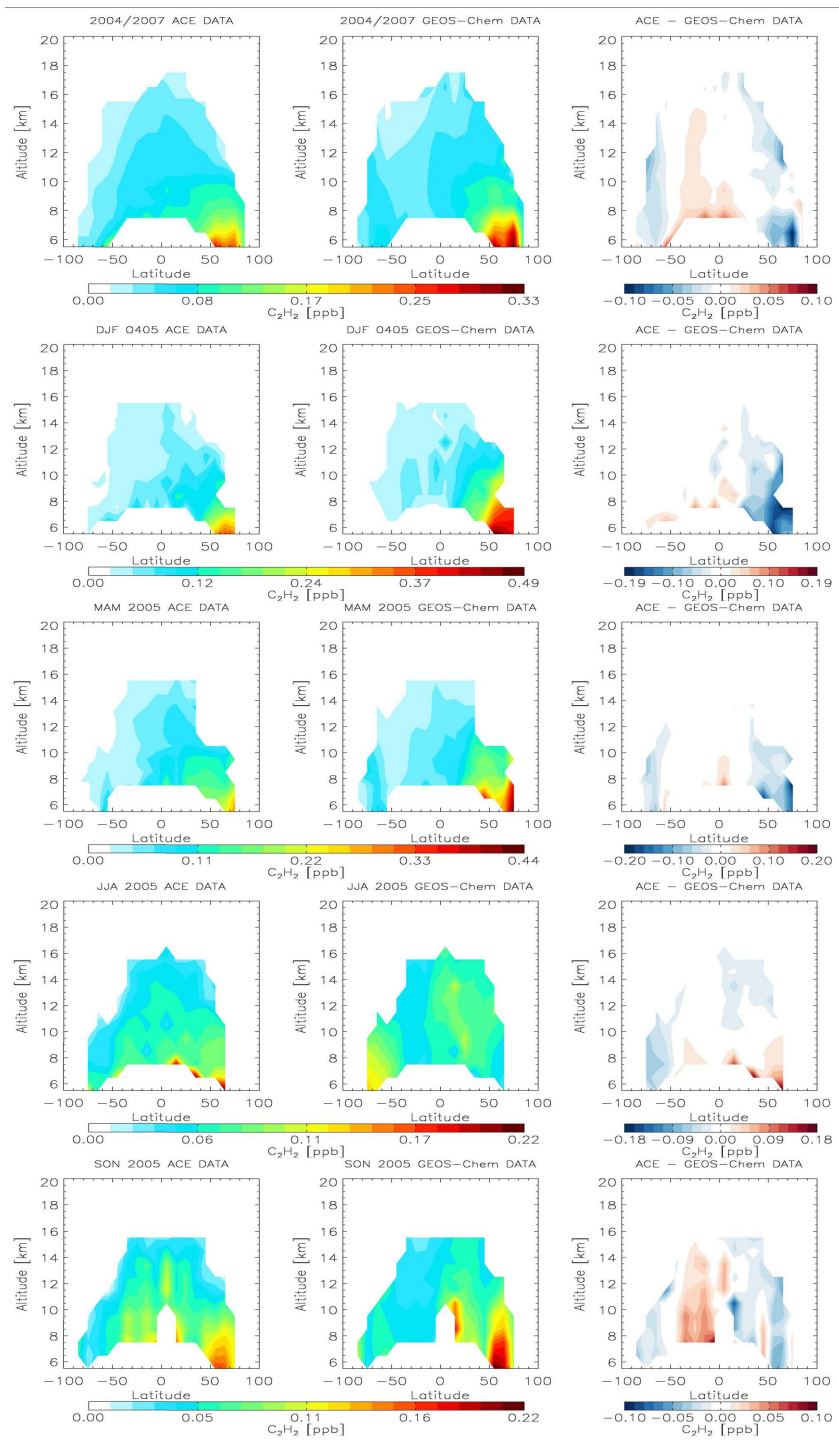

Fig. 10. $\mathrm{C}_{2} \mathrm{H}_{2}$ altitude-latitude cross sections from ACE left column, GEOS-Chem central column and difference between both data sets right column. Top panel full study time period, second panel December-January February 2004/2005, third panel March-AprilMay 2005, fourth panel June-July-August 2005 and fifth panel September-October-November 2005.

After this modification the model does well in the Southern Hemisphere where the effects of the bug in the emissions over Africa were dramatic. A more detailed comparison between the model and the ACE data is given below.

Figure 10 shows a near global middle to upper tropospheric ethyne concentration distribution observed from space. Due to ethyne's low concentrations the signature associated with it is sometimes weak in the ACE spectra, and fewer measurements are available for it than for $\mathrm{CO}$ and $\mathrm{C}_{2} \mathrm{H}_{6}$. These altitude-latitude cross sections of $\mathrm{C}_{2} \mathrm{H}_{2}$ show the expected features: hemispheric asymmetry with higher 


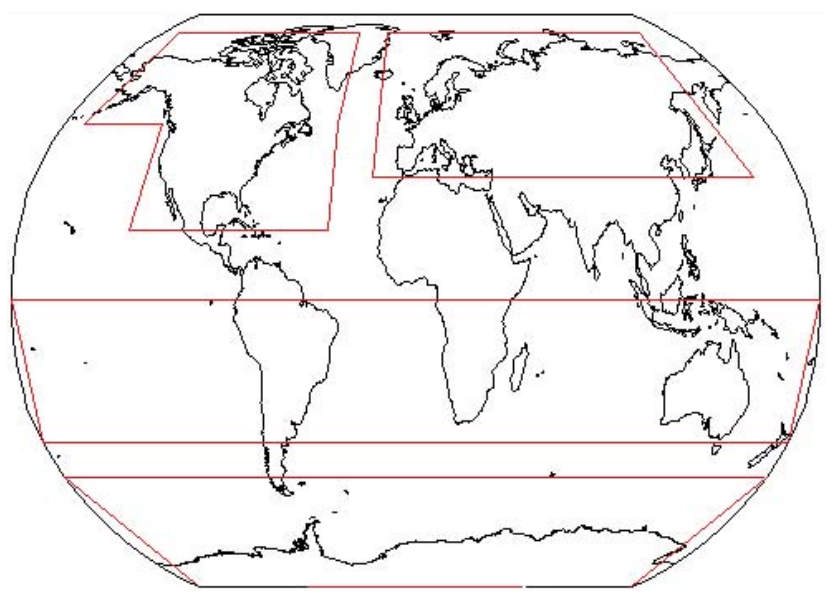

Fig. 11. Geographical regions selected for detailed comparison of ACE and GEOS-Chem data.
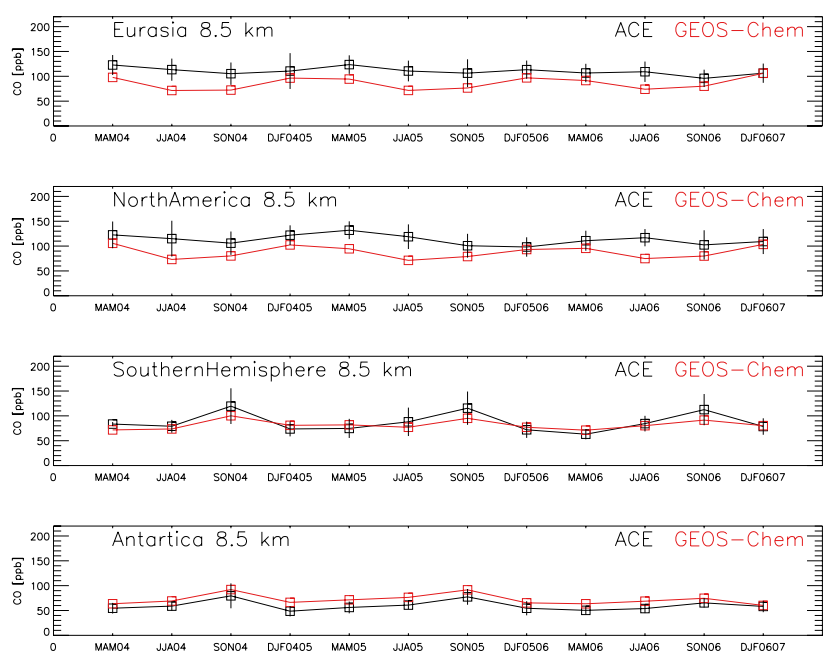

Fig. 12. Seasonal and hemispheric variations of $\mathrm{CO}$ volume mixing ratios observed (black) and simulated (red) averaged in different regions at $8.5 \mathrm{~km}$.

ethyne concentrations in the Northern Hemisphere, obviously linked to human activities and the use of biofuels, and the superimposed seasonal variation linked to emissions from fires and biomass burning episodes. High pollution episodes were also observed from the satellite but it is difficult to separate them from biomass burning plumes. Elevated upper troposphere concentrations from biomass burning emissions are easier to observe in the Southern Hemisphere where background concentrations are lower.

For a more detailed analysis of the model performance the data has been split into four geographical regions of particular interest (shown in Fig. 11). These regions are: North America (formed by two rectangular areas $170^{\circ} \mathrm{W}$, $40^{\circ} \mathrm{W}, 80^{\circ} \mathrm{N}, 50^{\circ} \mathrm{N}$ and $130^{\circ} \mathrm{W}, 40^{\circ} \mathrm{W}, 20^{\circ} \mathrm{N}, 50^{\circ} \mathrm{N}$ ), Eurasia $\left(20^{\circ} \mathrm{W}, 160^{\circ} \mathrm{E}, 80^{\circ} \mathrm{N}, 50^{\circ} \mathrm{N}\right)$, Southern Hemi-
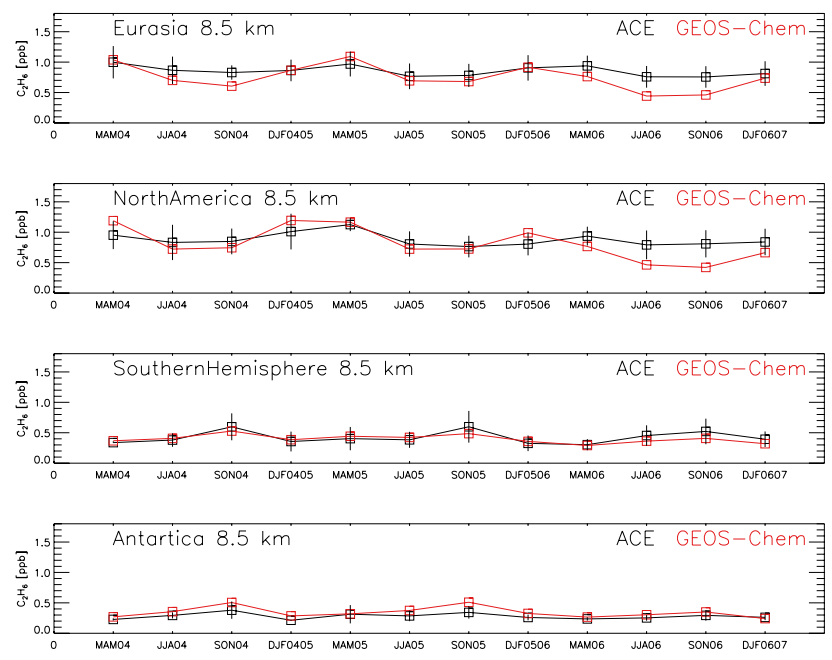

Fig. 13. Seasonal and hemispheric variations of $\mathrm{C}_{2} \mathrm{H}_{6}$ volume mixing ratios observed (black) and simulated (red) averaged in different regions at $8.5 \mathrm{~km}$.
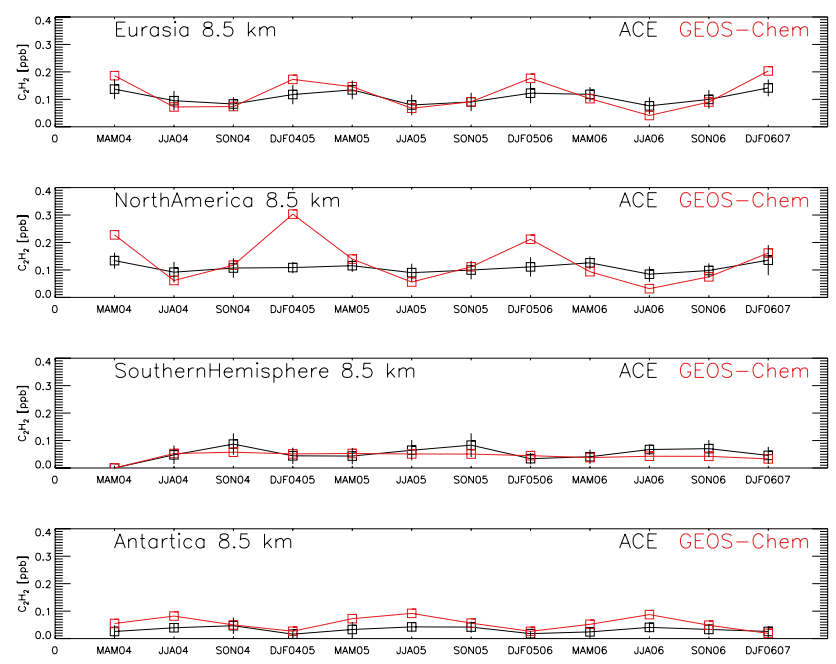

Fig. 14. Seasonal and hemispheric variations of $\mathrm{C}_{2} \mathrm{H}_{2}$ volume mixing ratios observed (black) and simulated (red) averaged in different regions at $8.5 \mathrm{~km}$.

sphere $\left(180^{\circ} \mathrm{W}, 180^{\circ} \mathrm{E}, 0^{\circ} \mathrm{S}, 40^{\circ} \mathrm{S}\right)$ and Antarctica $\left(180^{\circ} \mathrm{W}\right.$, $\left.180^{\circ} \mathrm{E}, 50^{\circ} \mathrm{S}, 90^{\circ} \mathrm{S}\right)$. In Figs. 12,13 and 14 time series of average ACE concentrations at $8.5 \mathrm{~km}$ (representative of the upper troposphere) have been plotted alongside the GEOSChem concentrations sampled in the same way as the satellite data. Figure 12 presents the results for $\mathrm{CO}$, Fig. 13 for $\mathrm{C}_{2} \mathrm{H}_{6}$ and Fig. 14 for $\mathrm{C}_{2} \mathrm{H}_{2}$ respectively. These three plots illustrate the seasonal variation for all three molecules as well as the hemispheric asymmetry in their concentrations. For these selected regions the mean bias (bias), the mean absolute bias (|bias $\mid)$ and the correlation coefficient between satellite and model data have been calculated as: 
Table 2. Statistical comparison between ACE retrieved CO concentrations and GEOS-Chem output at $8.5 \mathrm{~km}$ altitude; VMRs are expressed in ppb: $n$ is the number of data taken into account, bias is the Mean Bias as defined by Eq. (1), |bias| is the Mean Absolute Bias as defined by Eq. (2) and $r$ is the correlation coefficient.

\begin{tabular}{llrrrrrr}
\hline Region & Period & $n$ & $\begin{array}{r}\text { ACE-FTS } \\
\text { VMR (ppb) }\end{array}$ & $\begin{array}{r}\text { GEOS-Chem } \\
\text { VMR(ppb) }\end{array}$ & $\begin{array}{r}\text { Bias } \\
\%\end{array}$ & $\begin{array}{r}\mid \text { bias } \\
\%\end{array}$ & $r$ \\
\hline Global & Full & 2084 & 94 & 82 & -12 & 24 & 0.46 \\
North America* & DJF0405 & 6 & 122 & 102 & -16 & 19 & 0.50 \\
& MAM05 & 20 & 132 & 95 & -28 & 28 & 0.40 \\
& JJA05 & 24 & 119 & 71 & -40 & 41 & 0.08 \\
& SON05 & 26 & 101 & 79 & -21 & 30 & 0.18 \\
Eurasia* $^{*}$ & DJF0405 & 19 & 111 & 96 & -13 & 17 & 0.77 \\
& MAM05 & 19 & 124 & 94 & -24 & 25 & 0.22 \\
& JJA05 & 56 & 111 & 71 & -35 & 36 & 0.49 \\
Southern Hemisphere* & SON05 & 43 & 106 & 77 & -28 & 30 & 0.45 \\
& DJF0405 & 45 & 74 & 81 & 10 & 16 & 0.76 \\
& MAM05 & 38 & 75 & 82 & 9 & 15 & 0.67 \\
& JJA05 & 58 & 88 & 77 & -12 & 23 & 0.10 \\
Antarctic* & SON05 & 81 & 116 & 95 & -17 & 21 & 0.52 \\
& DJF0405 & 12 & 49 & 66 & 36 & 41 & 0.39 \\
& MAM05 & 39 & 56 & 71 & 27 & 28 & 0.48 \\
& JJA05 & 33 & 61 & 77 & 25 & 26 & 0.10 \\
& SON05 & 29 & 77 & 92 & 18 & 24 & 0.11 \\
\hline
\end{tabular}

${ }^{*}$ North America $\left(170^{\circ} \mathrm{W}, 40^{\circ} \mathrm{W}, 80^{\circ} \mathrm{N}, 50^{\circ} \mathrm{N}\right)$, Eurasia $\left(20^{\circ} \mathrm{W}, 160^{\circ} \mathrm{E}, 80^{\circ} \mathrm{N}, 50^{\circ} \mathrm{N}\right)$, Southern Hemisphere $\left(180^{\circ} \mathrm{W}, 180^{\circ} \mathrm{E}, 0^{\circ} \mathrm{S}, 40^{\circ} \mathrm{S}\right)$ and $\mathrm{Antarctica}\left(180^{\circ} \mathrm{W}, 180^{\circ} \mathrm{E}\right.$, $\left.50^{\circ} \mathrm{S}, 90^{\circ} \mathrm{S}\right)$.

$$
\begin{aligned}
& \text { bias }=\frac{\text { meanVMRmodel }- \text { meanVMRsatellite }}{\text { meanVMRsatellite }} \times 100 \\
& \mid \text { bias } \mid=\frac{\frac{1}{n} \Sigma_{i} \mid \text { VMRmodel }_{i}-\text { VMRsatellite }_{i} \mid}{\text { meanVMRsatellite }} \times 100
\end{aligned}
$$

This statistical analysis is summarized in Table 2 for CO, Table 3 for $\mathrm{C}_{2} \mathrm{H}_{6}$ and Table 4 for $\mathrm{C}_{2} \mathrm{H}_{2}$. The $\mathrm{CO}$ mean bias between ACE and GEOS-Chem is less than 30 percent for all the regions and seasons. Only North America and Eurasia JJA05 and Antarctica DJF0405 have greater mean biases. In general the model underestimates the $\mathrm{CO}$ concentration in the Northern Hemisphere while overestimating it in the Southern Hemisphere. The mean bias is always negative over North America and Eurasia but is always less than $40 \%$. For the case of the $\mathrm{C}_{2} \mathrm{H}_{6}$ the mean bias is smaller than $35 \%$ in all regions for all seasons and only in the Antarctic region does the model significantly overestimate the concentrations. As discussed above, the $\mathrm{C}_{2} \mathrm{H}_{6}$ emissions were modified in the model after finding a problem in the Southern regions of Africa; a more detailed study is needed to assess and improve the model performance in the polar latitudes of the Southern Hemisphere. Finally the analysis of $\mathrm{C}_{2} \mathrm{H}_{2}$ shows a high mean bias in North America for the DJF0405 season and in Antarctica for the MAM05 and JJA05 seasons. In general the seasonal variation of ethyne at $8.5 \mathrm{~km}$ is small according to the ACE data, while the model predicts a greater seasonal variation, linked to the emissions especially in the Northern Hemisphere. The long time series model simulations for $\mathrm{CO}, \mathrm{C}_{2} \mathrm{H}_{6}$ and $\mathrm{C}_{2} \mathrm{H}_{2}$ (which are shown on Figs. 12,
13 and 14) display a flatter behaviour than the corresponding satellite data. Fast transport of the emissions (especially biomass burning emissions) into the free troposphere could be the reason behind the observed discrepancies.

\section{Conclusions}

The near global tropospheric distributions of $\mathrm{CO}, \mathrm{C}_{2} \mathrm{H}_{6}$ and $\mathrm{C}_{2} \mathrm{H}_{2}$ have been presented using data from the ACE satellite. Approximately 8200 extravortex profiles were used in this study covering the period between February 2004 and September 2007. It has been possible to observe seasonal variations, and to relate these variations with the main sources of these trace gases: biomass burning and anthropogenic emissions. Values up to $250 \mathrm{ppb}$ have been observed for individual profiles of $\mathrm{CO}$, up to $2.5 \mathrm{ppb}$ for ethane and up to $0.5 \mathrm{ppb}$ for ethyne that are likely associated with biomass burning plumes or strong pollution events. The GEOS-Chem model has been run with the dicarbonyls extended chemistry and has been compared with the ACE-FTS observations. Agreement between the model and the satellite data is good having mean bias values smaller than $40 \%$ for all three molecules in all regions and seasons at $8.5 \mathrm{~km}$ in altitude. The only exception is the large high bias for $\mathrm{C}_{2} \mathrm{H}_{2}$ over Antarctica, as suggested in the main text this feature may be linked to the efficiency of the $\mathrm{OH}$ removal mechanism. The mean bias of the model relative to the observations 
Table 3. Statistical comparison between ACE retrieved $\mathrm{C}_{2} \mathrm{H}_{6}$ concentrations and GEOS-Chem output at $8.5 \mathrm{~km}$ altitude; VMRs are expressed in ppb: $n$ is the number of data taken into account, bias is the Mean Bias as defined by Eq. (1), |bias| is the Mean Absolute Bias as defined by Eq. (2) and $r$ is the correlation coefficient.

\begin{tabular}{|c|c|c|c|c|c|c|c|}
\hline Region & Period & $n$ & $\begin{array}{r}\text { ACE-FTS VMR } \\
\text { VMR (ppb) }\end{array}$ & $\begin{array}{r}\text { GEOS-Chem VMR } \\
\text { VMR(ppb) }\end{array}$ & $\begin{array}{r}\text { Bias } \\
\%\end{array}$ & $\begin{array}{r}\mid \text { bias } \mid \\
\%\end{array}$ & $r$ \\
\hline Global & Full & 1626 & 0.59 & 0.55 & -7 & 28 & 0.65 \\
\hline \multirow[t]{4}{*}{ North America* } & DJF0405 & 3 & 1.01 & 1.20 & 18 & 18 & 0.81 \\
\hline & MAM05 & 9 & 1.13 & 1.17 & 4 & 14 & 0.29 \\
\hline & JJA05 & 22 & 0.81 & 0.72 & -10 & 21 & 0.39 \\
\hline & SON05 & 22 & 0.76 & 0.73 & -5 & 25 & 0.23 \\
\hline \multirow[t]{4}{*}{ Eurasia* } & DJF0405 & 13 & 0.86 & 0.87 & 0.3 & 17 & 0.43 \\
\hline & MAM05 & 10 & 0.97 & 1.09 & 13 & 18 & 0.24 \\
\hline & JJA05 & 46 & 0.77 & 0.69 & -10 & 21 & 0.30 \\
\hline & SON05 & 35 & 0.78 & 0.68 & -13 & 22 & 0.51 \\
\hline \multirow[t]{4}{*}{ Southern Hemisphere* } & DJF0405 & 31 & 0.36 & 0.39 & 8 & 30 & 0.47 \\
\hline & MAM05 & 27 & 0.40 & 0.44 & 10 & 28 & 0.72 \\
\hline & JJA05 & 53 & 0.38 & 0.42 & 10 & 30 & 0.15 \\
\hline & SON05 & 65 & 0.60 & 0.49 & -19 & 32 & 0.52 \\
\hline \multirow[t]{4}{*}{ Antarctic* } & DJF0405 & 2 & 0.21 & 0.29 & 33 & 33 & 1.00 \\
\hline & MAM05 & 22 & 0.31 & 0.32 & 2 & 36 & 0.19 \\
\hline & JJA05 & 25 & 0.29 & 0.38 & 31 & 40 & 0.10 \\
\hline & SON05 & 27 & 0.34 & 0.51 & 47 & 50 & 0.23 \\
\hline
\end{tabular}

${ }^{*}$ North America $\left(170^{\circ} \mathrm{W}, 40^{\circ} \mathrm{W}, 80^{\circ} \mathrm{N}, 50^{\circ} \mathrm{N}\right)$, Eurasia $\left(20^{\circ} \mathrm{W}, 160^{\circ} \mathrm{E}, 80^{\circ} \mathrm{N}, 50^{\circ} \mathrm{N}\right)$, Southern Hemisphere $\left(180^{\circ} \mathrm{W}, 180^{\circ} \mathrm{E}, 0^{\circ} \mathrm{S}, 40^{\circ} \mathrm{S}\right)$ and $\mathrm{Antarctica}\left(180^{\circ} \mathrm{W}, 180^{\circ} \mathrm{E}\right.$, $\left.50^{\circ} \mathrm{S}, 90^{\circ} \mathrm{S}\right)$.

Table 4. Statistical comparison between ACE retrieved $\mathrm{C}_{2} \mathrm{H}_{2}$ concentrations and GEOS-Chem output at $8.5 \mathrm{~km}$ altitude; VMRs are expressed in ppb: $n$ is the number of data taken into account, bias is the Mean Bias as defined by Eq. (1), |bias| is the Mean Absolute Bias as defined by Eq. (2) and $r$ is the correlation coefficient.

\begin{tabular}{|c|c|c|c|c|c|c|c|}
\hline Region & Period & $n$ & $\begin{array}{r}\text { ACE-FTS VMR } \\
\text { VMR (ppb) }\end{array}$ & $\begin{array}{r}\text { GEOS-Chem VMR } \\
\text { VMR(ppb) }\end{array}$ & $\begin{array}{r}\text { Bias } \\
\%\end{array}$ & $\begin{array}{r}\mid \text { bias } \mid \\
\%\end{array}$ & $r$ \\
\hline Global & Full & 1696 & 0.071 & 0.072 & 1 & 49 & 0.51 \\
\hline \multirow[t]{4}{*}{ North America* } & DJF0405 & 2 & 0.109 & 0.303 & 179 & 179 & 1.00 \\
\hline & MAM05 & 16 & 0.116 & 0.140 & 21 & 32 & 0.38 \\
\hline & JJA05 & 22 & 0.090 & 0.056 & -38 & 42 & 0.02 \\
\hline & SON05 & 25 & 0.100 & 0.111 & 12 & 47 & 0.02 \\
\hline \multirow[t]{4}{*}{ Eurasia* } & DJF0405 & 13 & 0.118 & 0.173 & 47 & 50 & 0.15 \\
\hline & MAM05 & 14 & 0.134 & 0.146 & 8 & 17 & 0.74 \\
\hline & JJA05 & 46 & 0.079 & 0.067 & -15 & 37 & 0.41 \\
\hline & SON05 & 35 & 0.091 & 0.091 & 1 & 39 & 0.40 \\
\hline \multirow[t]{4}{*}{ Southern Hemisphere* } & DJF0405 & 37 & 0.044 & 0.051 & 16 & 66 & 0.28 \\
\hline & MAM05 & 30 & 0.044 & 0.053 & 21 & 55 & 0.35 \\
\hline & JJA05 & 52 & 0.065 & 0.051 & -21 & 36 & 0.34 \\
\hline & SON05 & 57 & 0.083 & 0.051 & -39 & 44 & 0.52 \\
\hline \multirow[t]{4}{*}{ Antarctic* } & DJF0405 & 10 & 0.016 & 0.027 & 66 & 73 & 0.46 \\
\hline & MAM05 & 30 & 0.033 & 0.072 & 119 & 139 & 0.10 \\
\hline & JJA05 & 32 & 0.043 & 0.092 & 115 & 115 & 0.03 \\
\hline & SON05 & 29 & 0.042 & 0.056 & 34 & 45 & 0.71 \\
\hline
\end{tabular}

${ }^{*}$ North America $\left(170^{\circ} \mathrm{W}, 40^{\circ} \mathrm{W}, 80^{\circ} \mathrm{N}, 50^{\circ} \mathrm{N}\right)$, Eurasia $\left(20^{\circ} \mathrm{W}, 160^{\circ} \mathrm{E}, 80^{\circ} \mathrm{N}, 50^{\circ} \mathrm{N}\right)$, Southern Hemisphere $\left(180^{\circ} \mathrm{W}, 180^{\circ} \mathrm{E}, 0^{\circ} \mathrm{S}, 40^{\circ} \mathrm{S}\right)$ and $\mathrm{Antarctica}\left(180^{\circ} \mathrm{W}, 180^{\circ} \mathrm{E}\right.$, $\left.50^{\circ} \mathrm{S}, 90^{\circ} \mathrm{S}\right)$.

for all data at $8.5 \mathrm{~km}$ is $-12 \%$ for $\mathrm{CO},-7 \%$ for $\mathrm{C}_{2} \mathrm{H}_{6}$ and $1 \%$ for $\mathrm{C}_{2} \mathrm{H}_{2}$. The hemispheric asymmetry and seasonal variation observed for all three molecule concentrations has been linked to changes in anthropogenic and biomass burning emissions. The ACE data have been compared with similar measurements made by the balloon-borne MkIV-FTS and 
with aircraft data obtained in the GTE TRACE-A campaign showing that the ACE retrievals are reliable in the upper troposphere lower stratosphere region.

\section{Supplementary material related to this article is available online at: \\ http://www.atmos-chem-phys.net/11/9927/2011/ acp-11-9927-2011-supplement.pdf.}

Acknowledgements. The ACE mission is funded primarily by the Canadian Space Agency. Funding was also provided by the UK Natural Environment Research Council (NERC), in part through the National Centre for Earth Observation (NCEO). Gonzalo González Abad thanks the Wild Fund for support. Work at the Jet Propulsion Laboratory, California Institute of Technology, was done under contract with the National Aeronautics and Space Administration.

Edited by: P. Monks

\section{References}

Auvray, M. and Bey, I.: Long-range transport to Europe: Seasonal variations and implications for the European ozone budget, J. Geophys. Res.-Atmos., 110, D11303, doi:10.1029/2004JD005503, 2005.

Barret, B., Ricaud, P., Santee, M. L., Attie, J. L., Urban, J., Le Flochmoen, E., Berthet, G., Murtagh, D., Eriksson, P., Jones, A., de la Noe, J., Dupuy, E., Froidevaux, L., Livesey, N. J., Waters, J. W., and Filipiak, M. J.: Intercomparisons of trace gases profiles from the Odin/SMR and Aura/MLS limb sounders, J. Geophys. Res.-Atmos., 111, D21302, doi:10.1029/2006jd007305, 2006.

Bernath, P. F.: Atmospheric chemistry experiment (ACE): Analytical chemistry from orbit, TrAC, Trends Anal. Chem., 25, 647654, doi:10.1016/j.trac.2006.05.001, 2006.

Bernath, P. F., McElroy, C. T., Abrams, M. C., Boone, C. D., Butler, M., Camy-Peyret, C., Carleer, M., Clerbaux, C., Coheur, P. F., Colin, R., DeCola, P., DeMaziere, M., Drummond, J. R., Dufour, D., Evans, W. F. J., Fast, H., Fussen, D., Gilbert, K., Jennings, D. E., Llewellyn, E. J., Lowe, R. P., Mahieu, E., McConnell, J. C., McHugh, M., McLeod, S. D., Michaud, R., Midwinter, C., Nassar, R., Nichitiu, F., Nowlan, C., Rinsland, C. P., Rochon, Y. J., Rowlands, N., Semeniuk, K., Simon, P., Skelton, R., Sloan, J. J., Soucy, M. A., Strong, K., Tremblay, P., Turnbull, D., Walker, K. A., Walkty, I., Wardle, D. A., Wehrle, V., Zander, R., and Zou, J.: Atmospheric Chemistry Experiment (ACE): Mission overview, Geophys. Res. Lett., 32, L15S01, doi:10.1029/2005g1022386, 2005.

Bey, I., Jacob, D. J., Yantosca, R. M., Logan, J. A., Field, B. D., Fiore, A. M., Li, Q. B., Liu, H. G. Y., Mickley, L. J., and Schultz, M. G.: Global modeling of tropospheric chemistry with assimilated meteorology: Model description and evaluation, J. Geophys. Res.-Atmos., 106, 23073-23095, doi:10.1029/2001JD000807, 2001.

Blake, N. J., Blake, D. R., Sive, B. C., Chen, T. Y., Rowland, F. S., Collins, J. E., Sachse, G. W., and Anderson, B. E.: Biomass burning emissions and vertical distribution of atmospheric methyl halides and other reduced carbon gases in the
South Atlantic region, J. Geophys. Res.-Atmos., 101, 2415124164, doi:10.1029/96JD00561, 1996.

Boone, C. D., Nassar, R., Walker, K. A., Rochon, Y., McLeod, S. D., Rinsland, C. P., and Bernath, P. F.: Retrievals for the atmospheric chemistry experiment Fourier-transform spectrometer, Appl. Opt., 44, 7218-7231, doi:10.1364/AO.44.007218, 2005.

Buchwitz, M., de Beek, R., Noël, S., Burrows, J. P., Bovensmann, H., Schneising, O., Khlystova, I., Bruns, M., Bremer, H., Bergamaschi, P., Körner, S., and Heimann, M.: Atmospheric carbon gases retrieved from SCIAMACHY by WFM-DOAS: version $0.5 \mathrm{CO}$ and $\mathrm{CH}_{4}$ and impact of calibration improvements on $\mathrm{CO}_{2}$ retrieval, Atmos. Chem. Phys., 6, 2727-2751, doi:10.5194/acp6-2727-2006, 2006.

Chatfield, R. B., Vastano, J. A., Li, L., Sachse, G. W., and Connors, V. S.: The Great African plume from biomass burning: Generalizations from a three-dimensional study of TRACE A carbon monoxide, J. Geophys. Res.-Atmos., 103, 28059-28077, doi:10.1029/97JD03363, 1998.

Clerbaux, C., Coheur, P. F., Hurtmans, D., Barret, B., Carleer, M., Colin, R., Semeniuk, K., McConnell, J. C., Boone, C., and Bernath, P.: Carbon monoxide distribution from the ACEFTS solar occultation measurements, Geophys. Res. Lett., 32, doi:10.1029/2005g1022394, 2005.

Clerbaux, C., George, M., Turquety, S., Walker, K. A., Barret, B., Bernath, P., Boone, C., Borsdorff, T., Cammas, J. P., Catoire, V., Coffey, M., Coheur, P.-F., Deeter, M., De Maziére, M., Drummond, J., Duchatelet, P., Dupuy, E., de Zafra, R., Eddounia, F., Edwards, D. P., Emmons, L., Funke, B., Gille, J., Griffith, D. W. T., Hannigan, J., Hase, F., Höpfner, M., Jones, N., Kagawa, A., Kasai, Y., Kramer, I., Le Flochmoën, E., Livesey, N. J., Lòpez-Puertas, M., Luo, M., Mahieu, E., Murtagh, D., Nédélec, P., Pazmino, A., Pumphrey, H., Ricaud, P., Rinsland, C. P., Robert, C., Schneider, M., Senten, C., Stiller, G., Strandberg, A., Strong, K., Sussmann, R., Thouret, V., Urban, J., and Wiacek, A.: CO measurements from the ACE-FTS satellite instrument: data analysis and validation using ground-based, airborne and spaceborne observations, Atmos. Chem. Phys., 8, 2569-2594, doi:10.5194/acp-8-2569-2008, 2008.

Deeter, M. N., Emmons, L. K., Francis, G. L., Edwards, D. P., Gille, J. C., Warner, J. X., Khattatov, B., Ziskin, D., Lamarque, J. F., Ho, S. P., Yudin, V., Attie, J. L., Packman, D., Chen, J., Mao, D., and Drummond, J. R.: Operational carbon monoxide retrieval algorithm and selected results for the MOPITT instrument, J. Geophys. Res.-Atmos., 108, 4399, doi:10.1029/2002jd003186, 2003.

Dufour, G., Szopa, S., Barkley, M. P., Boone, C. D., Perrin, A., Palmer, P. I., and Bernath, P. F.: Global uppertropospheric formaldehyde: seasonal cycles observed by the ACE-FTS satellite instrument, Atmos. Chem. Phys., 9, 38933910, doi:10.5194/acp-9-3893-2009, 2009.

Fishman, J., Hoell, J. M., Bendura, R. D., McNeil, R. J., and Kirchhoff, V.: NASA GTE TRACE A experiment (September October 1992): Overview, J. Geophys. Res.-Atmos., 101, 23865-23879, doi:10.1029/96JD00123, 1996.

Fu, T. M., Jacob, D. J., Wittrock, F., Burrows, J. P., Vrekoussis, M., and Henze, D. K.: Global budgets of atmospheric glyoxal and methylglyoxal, and implications for formation of secondary organic aerosols, J. Geophys. Res.-Atmos., 113, doi:10.1029/2007jd009505, 2008. 
Funke, B., Lopez-Puertas, M., Bermejo-Pantaleon, D., von Clarmann, T., Stiller, G. P., Hopfner, M., Grabowski, U., and Kaufmann, M.: Analysis of nonlocal thermodynamic equilibrium CO $4.7 \mu \mathrm{m}$ fundamental, isotopic, and hot band emissions measured by the Michelson Interferometer for Passive Atmospheric Sounding on Envisat, J. Geophys. Res.-Atmos., 112, D11305, doi:10.1029/2006jd007933, 2007.

Giglio, L., van der Werf, G. R., Randerson, J. T., Collatz, G. J., and Kasibhatla, P.: Global estimation of burned area using MODIS active fire observations, Atmos. Chem. Phys., 6, 957974, doi:10.5194/acp-6-957-2006, 2006.

Glatthor, N., von Clarmann, T., Fischer, H., Funke, B., Grabowski, U., Höpfner, M., Kellmann, S., Kiefer, M., Linden, A., Milz, M., Steck, T., and Stiller, G. P.: Global peroxyacetyl nitrate (PAN) retrieval in the upper troposphere from limb emission spectra of the Michelson Interferometer for Passive Atmospheric Sounding (MIPAS), Atmos. Chem. Phys., 7, 2775-2787, doi:10.5194/acp7-2775-2007, 2007.

Glatthor, N., von Clarmann, T., Stiller, G. P., Funke, B., Koukouli, M. E., Fischer, H., Grabowski, U., Höpfner, M., Kellmann, S., and Linden, A.: Large-scale upper tropospheric pollution observed by MIPAS HCN and $\mathrm{C}_{2} \mathrm{H}_{6}$ global distributions, Atmos. Chem. Phys., 9, 9619-9634, doi:10.5194/acp-9-9619-2009, 2009.

Gupta, M. L., Cicerone, R. J., Blake, D. R., Rowland, F. S., and Isaksen, I. S. A.: Global atmospheric distributions and source strengths of light hydrocarbons and tetrachloroethene, J. Geophys. Res.-Atmos., 103, 28219-28235, doi:10.1029/98JD02645, 1998.

Horowitz, L. W., Liang, J. Y., Gardner, G. M., and Jacob, D. J.: Export of reactive nitrogen from North America during summertime: Sensitivity to hydrocarbon chemistry, J. Geophys. Res.Atmos., 103, 13451-13476, doi:10.1029/97JD03142, 1998.

Hudman, R. C., Murray, L. T., Jacob, D. J., Millet, D. B., Turquety, S., Wu, S., Blake, D. R., Goldstein, A. H., Holloway, J., and Sachse, G. W.: Biogenic versus anthropogenic sources of CO in the United States, Geophys. Res. Lett., 35, L04801, doi:10.1029/2007g1032393, 2008.

Irion, F. W., Gunson, M. R., Toon, G. C., Chang, A. Y., Eldering, A., Mahieu, E., Manney, G. L., Michelsen, H. A., Moyer, E. J., Newchurch, M. J., Osterman, G. B., Rinsland, C. P., Salawitch, R. J., Sen, B., Yung, Y. L., and Zander, R.: Atmospheric Trace Molecule Spectroscopy (ATMOS) experiment version 3 data retrievals, Appl. Optics, 41, 6968-6979, doi:10.1364/AO.41.006968, 2002.

Kopacz, M., Jacob, D. J., Fisher, J. A., Logan, J. A., Zhang, L., Megretskaia, I. A., Yantosca, R. M., Singh, K., Henze, D. K., Burrows, J. P., Buchwitz, M., Khlystova, I., McMillan, W. W., Gille, J. C., Edwards, D. P., Eldering, A., Thouret, V., and Nedelec, P.: Global estimates of CO sources with high resolution by adjoint inversion of multiple satellite datasets (MOPITT, AIRS, SCIAMACHY, TES), Atmos. Chem. Phys., 10, 855-876, doi:10.5194/acp-10-855-2010, 2010.

Kuhns, H., Knipping, E. M., and Vukovich, J. M.: Development of a United States-Mexico emissions inventory for the Big Bend Regional Aerosol and Visibility Observational (BRAVO) Study, J. Air Waste Manage., 55, 677-692, 2005.

Logan, J. A., Prather, M. J., Wofsy, S. C., and McElroy, M. B.: Tropospheric chemistry - a global perspective, J. Geophys. Res.-
Ocean Atmos., 86, 7210-7254, doi:10.1029/JC086iC08p07210, 1981.

Luo, M., Rinsland, C. P., Rodgers, C. D., Logan, J. A., Worden, H., Kulawik, S., Eldering, A., Goldman, A., Shephard, M. W., Gunson, M., and Lampel, M.: Comparison of carbon monoxide measurements by TES and MOPITT: Influence of a priori data and instrument characteristics on nadir atmospheric species retrievals, J. Geophys. Res.-Atmos., 112, D09303, doi:10.1029/2006jd007663, 2007.

Manney, G. L., Daffer, W. H., Zawodny, J. M., Bernath, P. F., Hoppel, K. W., Walker, K. A., Knosp, B. W., Boone, C., Remsberg, E. E., Santee, M. L., Harvey, V. L., Pawson, S., Jackson, D. R., Deaver, L., McElroy, C. T., McLinden, C. A., Drummond, J. R., Pumphrey, H. C., Lambert, A., Schwartz, M. J., Froidevaux, L., McLeod, S., Takacs, L. L., Suarez, M. J., Trepte, C. R., Cuddy, D. C., Livesey, N. J., Harwood, R. S., and Waters, J. W.: Solar occultation satellite data and derived meteorological products: Sampling issues and comparisons with Aura Microwave Limb Sounder, J. Geophys. Res.-Atmos., 112, D24S50, doi:10.1029/2007jd008709, 2007.

Martin, R. V., Jacob, D. J., Yantosca, R. M., Chin, M., and Ginoux, P.: Global and regional decreases in tropospheric oxidants from photochemical effects of aerosols, J. Geophys. Res.-Atmos., 108, 4097, doi:10.1029/2002jd002622, 2003.

McHugh, M., Magill, B., Walker, K. A., Boone, C. D., Bernath, P. F., and Russell, J. M.: Comparison of atmospheric retrievals from ACE and HALOE, Geophys. Res. Lett., 32, L15S10, doi:10.1029/2005g1022403, 2005.

Nassar, R., Bernath, P. F., Boone, C. D., Manney, G. L., McLeod, S. D., Rinsland, C. P., Skelton, R., and Walker, K. A.: ACE-FTS measurements across the edge of the winter 2004 Arctic vortex, Geophys. Res. Lett., 32, L15S05, doi:10.1029/2005gl022671, 2005.

Notholt, J., Toon, G., Stordal, F., Solberg, S., Schmidbauer, N., Becker, E., Meier, A., and Sen, B.: Seasonal variations of atmospheric trace gases in the high Arctic at $79^{\circ} \mathrm{N}$, J. Geophys. Res.-Atmos., 102, 12855-12861, doi:10.1029/97JD00337, 1997.

Park, M., Randel, W. J., Emmons, L. K., Bernath, P. F., Walker, K. A., and Boone, C. D.: Chemical isolation in the Asian monsoon anticyclone observed in Atmospheric Chemistry Experiment (ACE-FTS) data, Atmos. Chem. Phys., 8, 757-764, doi:10.5194/acp-8-757-2008, 2008.

Parker, R. J., Remedios, J. J., Moore, D. P., and Kanawade, V. P.: Acetylene $\mathrm{C}_{2} \mathrm{H}_{2}$ retrievals from MIPAS data and regions of enhanced upper tropospheric concentrations in $\mathrm{Au}-$ gust 2003, Atmos. Chem. Phys. Discuss., 10, 29735-29771, doi:10.5194/acpd-10-29735-2010, 2010.

Pumphrey, H. C., Filipiak, M. J., Livesey, N. J., Schwartz, M. J., Boone, C., Walker, K. A., Bernath, P., Ricaud, P., Barret, B., Clerbaux, C., Jarnot, R. F., Manney, G. L., and Waters, J. W.: Validation of middle-atmosphere carbon monoxide retrievals from the Microwave Limb Sounder on Aura, J. Geophys. Res.Atmos., 112, D24S38, doi:10.1029/2007jd008723, 2007.

Rinsland, C. P., Salawitch, R. J., Osterman, G. B., Irion, F. W., Sen, B., Zander, R., Mahieu, E., and Gunson, M. R.: Stratospheric CO at tropical and mid-latitudes: ATMOS measurements and photochemical steady-state model calculations, Geophys. Res. Lett., 27, 1395-1398, doi:10.1029/1999GL011184, 2000.

Rinsland, C. P., Jones, N. B., Connor, B. J., Wood, S. W., Gold- 
man, A., Stephen, T. M., Murcray, F. J., Chiou, L. S., Zander, R., and Mahieu, E.: Multiyear infrared solar spectroscopic measurements of $\mathrm{HCN}, \mathrm{CO}, \mathrm{C}_{2} \mathrm{H}_{6}$, and $\mathrm{C}_{2} \mathrm{H}_{2}$ tropospheric columns above Lauder, New Zealand ( $45^{\circ} \mathrm{S}$ latitude), J. Geophys. Res.Atmos., 107, doi:10.1029/2001jd001150, 2002.

Rinsland, C. P., Dufour, G., Boone, C. D., Bernath, P. F., and Chiou, L.: Atmospheric Chemistry Experiment (ACE) measurements of elevated Southern Hemisphere upper tropospheric CO, $\mathrm{C}_{2} \mathrm{H}_{6}, \mathrm{HCN}$, and $\mathrm{C}_{2} \mathrm{H}_{2}$ mixing ratios from biomass burning emissions and long-range transport, Geophys. Res. Lett., 32, L20803, doi:10.1029/2005GL024214, 2005.

Rothman, L. S., Jacquemart, D., Barbe, A., Chrus Benner, D., Birk, M., Brown, L. R.,, Carleer, M. R., Chackerian Jr., C., Chance, K., Coudert, L. H., Dana, V., Devi, V. M., Flaud, J.-M., Gamache, R. R., Goldman, A., Hartmann, J.-M., Jucks, K. W., Maki, A. G., Mandin, J.-Y., Massie, S. T., Orphal, J., Perrin, A., Rinsland, C. P., Smith, M. A. H., Tennyson, J., Tolchenov, R. N., Toth, R. A., Vander Auwera, J., Varanasi, P., and Wagner, G.: The HITRAN 2004 molecular spectroscopic database, J. Quant. Spectrosc. Ra., 96, 139-204, doi:10.1016/j.jqsrt.2004.10.008, 2005.

Rudolph, J.: The tropospheric distribution and budget of ethane, J. Geophys. Res.-Atmos., 100, 11369-11381, doi:10.1029/95JD00693, 1995.

Sen, B., Toon, G. C., Osterman, G. B., Blavier, J. F., Margitan, J. J., Salawitch, R. J., and Yue, G. K.: Measurements of reactive nitrogen in the stratosphere, J. Geophys. Res.-Atmos., 103, 3571-3585, doi:10.1029/97JD02468, 1998.

Sica, R. J., Izawa, M. R. M., Walker, K. A., Boone, C., Petelina, S. V., Argall, P. S., Bernath, P., Burns, G. B., Catoire, V., Collins, R. L., Daffer, W. H., De Clercq, C., Fan, Z. Y., Firanski, B. J., French, W. J. R., Gerard, P., Gerding, M., Granville, J., Innis, J. L., Keckhut, P., Kerzenmacher, T., Klekociuk, A. R., Kyrö, E., Lambert, J. C., Llewellyn, E. J., Manney, G. L., McDermid, I. S., Mizutani, K., Murayama, Y., Piccolo, C., Raspollini, P., Ridolfi, M., Robert, C., Steinbrecht, W., Strawbridge, K. B., Strong, K., Stbi, R., and Thurairajah, B.: Validation of the Atmospheric Chemistry Experiment (ACE) version 2.2 temperature using ground-based and space-borne measurements, Atmos. Chem. Phys., 8, 35-62, doi:10.5194/acp-8-35-2008, 2008.

Tereszchuk, K. A., González Abad, G., Clerbaux, C., Hurtmans, D., Coheur, P.-F., and Bernath, P. F.: ACE-FTS measurements of trace species in the characterization of biomass burning plumes, Atmos. Chem. Phys. Discuss., 11, 16611-16637, doi:10.5194/acpd-11-16611-2011, 2011.
Toon, G. C.: The JPL MkIV Interferometer, Optics and Photonics News, 2, 19-21, doi:10.1364/OPN.2.10.000019, 1991.

Turquety, S., Clerbaux, C., Law, K., Coheur, P.-F., Cozic, A., Szopa, S., Hauglustaine, D. A., Hadji-Lazaro, J., Gloudemans, A. M. S., Schrijver, H., Boone, C. D., Bernath, P. F., and Edwards, D. P.: CO emission and export from Asia: an analysis combining complementary satellite measurements (MOPITT, SCIAMACHY and ACE-FTS) with global modeling, Atmos. Chem. Phys., 8, 5187-5204, doi:10.5194/acp-8-5187-2008, 2008.

Volkamer, R., Ziemann, P. J., and Molina, M. J.: Secondary Organic Aerosol Formation from Acetylene $\left(\mathrm{C}_{2} \mathrm{H}_{2}\right)$ : seed effect on SOA yields due to organic photochemistry in the aerosol aqueous phase, Atmos. Chem. Phys., 9, 1907-1928, doi:10.5194/acp9-1907-2009, 2009.

Wang, Y. H., Jacob, D. J., and Logan, J. A.: Global simulation of tropospheric $\mathrm{O}_{3}-\mathrm{NO}_{\mathrm{x}}$-hydrocarbon chemistry 1. Model formulation, J. Geophys. Res.-Atmos., 103, 10713-10725, doi:10.1029/98JD00158, 1998.

Xiao, Y. P., Jacob, D. J., and Turquety, S.: Atmospheric acetylene and its relationship with $\mathrm{CO}$ as an indicator of air mass age, J. Geophys. Res.-Atmos., 112, D12305, doi:10.1029/2006jd008268, 2007.

Xiao, Y. P., Logan, J. A., Jacob, D. J., Hudman, R. C., Yantosca, R., and Blake, D. R.: Global budget of ethane and regional constraints on US sources, J. Geophys. Res.-Atmos., 113, D21306, doi:10.1029/2007jd009415, 2008.

Yevich, R. and Logan, J. A.: An assessment of biofuel use and burning of agricultural waste in the developing world, Global Biogeochem. Cy., 17, doi:10.1029/2002gb001952, 2003.

Zhang, Q., Streets, D. G., Carmichael, G. R., He, K. B., Huo, H., Kannari, A., Klimont, Z., Park, I. S., Reddy, S., Fu, J. S., Chen, D., Duan, L., Lei, Y., Wang, L. T., and Yao, Z. L.: Asian emissions in 2006 for the NASA INTEX-B mission, Atmos. Chem. Phys., 9, 5131-5153, doi:10.5194/acp-9-5131-2009, 2009.

Zhao, Y., Strong, K., Kondo, Y., Koike, M., Matsumi, Y., Irie, H., Rinsland, C. P., Jones, N. B., Suzuki, K., Nakajima, H., Nakane, H., and Murata, I.: Spectroscopic measurements of tropospheric $\mathrm{CO}, \mathrm{C}_{2} \mathrm{H}_{6}, \mathrm{C}_{2} \mathrm{H}_{2}$, and $\mathrm{HCN}$ in northern Japan, J. Geophys. Res.Atmos., 107, 4343, doi:10.1029/2001jd000748, 2002. 